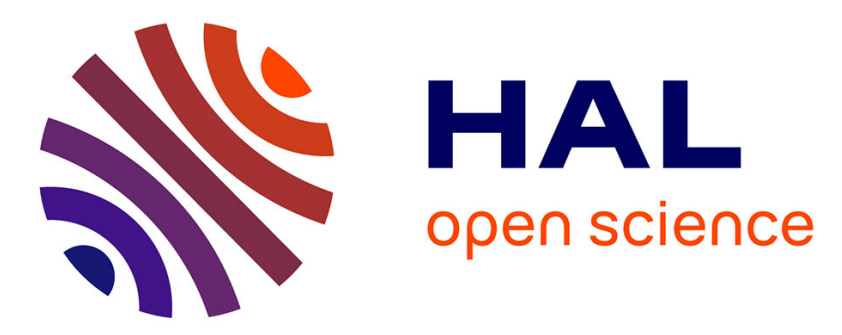

\title{
A Study of the Hydro-Mechanical Behaviour of Compacted Crushed Argillite
}

Chaosheng Tang, Anh Minh A.M. Tang, Yu-Jun Cui, Pierre Delage, Christian Schroeder, Bin Shi

\section{- To cite this version:}

Chaosheng Tang, Anh Minh A.M. Tang, Yu-Jun Cui, Pierre Delage, Christian Schroeder, et al.. A Study of the Hydro-Mechanical Behaviour of Compacted Crushed Argillite. Engineering Geology, 2011, 118 (3-4), pp.93-103. 10.1016/j.enggeo.2011.01.004 . hal-00574332

\section{HAL Id: hal-00574332 \\ https://hal.science/hal-00574332}

Submitted on 7 Mar 2011

HAL is a multi-disciplinary open access archive for the deposit and dissemination of scientific research documents, whether they are published or not. The documents may come from teaching and research institutions in France or abroad, or from public or private research centers.
L'archive ouverte pluridisciplinaire HAL, est destinée au dépôt et à la diffusion de documents scientifiques de niveau recherche, publiés ou non, émanant des établissements d'enseignement et de recherche français ou étrangers, des laboratoires publics ou privés. 


\title{
A Study of the Hydro-Mechanical Behaviour of Compacted Crushed Argillite
}

\author{
C.S. Tang ${ }^{\text {a, }}$, A.M. Tang ${ }^{b}$, Y.J. Cui ${ }^{b}$, P. Delage ${ }^{b}$, C. Schroeder ${ }^{c}$, B. Shi ${ }^{\text {a }}$ \\ ${ }^{a}$ School of Earth Sciences and Engineering, Nanjing University, China \\ ${ }^{b}$ Ecole des Ponts-ParisTech, UR Navier/CERMES, France \\ ${ }^{c}$ ANDRA, France
}

\section{Corresponding author:}

\section{Prof. Yu-Jun Cui}

ENPC/CERMES

6 et 8 avenue Blaise Pascal,

Cité Descartes, Champs-sur-Marne,

77455 MARNE-LA-VALLEE CEDEX 2,

France.

Tel: 33164153550

Fax: 33164153562

E-mail: yujun.cui@enpc.fr 


\begin{abstract}
The argillite extracted from Bure site (France) is proposed, after being crushed and compacted, as a possible sealing and backfill material in the geological high-level radioactive waste disposal. In this study, the effects of the grain size distribution and the microstructure on the hydro-mechanical behaviour of the compacted crushed argillite have been investigated. The volume change properties were investigated by running one-dimensional compression tests under constant water content (2.4-2.8\%) with loading-unloading cycles. Under various vertical stresses, water flooding tests were carried out in constant volume condition. Depending on the vertical stress level, either swelling or collapse behavior was observed in the sense that vertical stress increased or decreased upon flooding respectively. A clear effect of grain size distribution has been also identified: finer samples exhibit stiffer compression behaviour and higher swelling potential. To provide a microstructure insight into the macroscopic behaviour feature observed, both mercury intrusion porosimetry (MIP) and scanning electron microscopy (SEM) observations were performed, evidencing that: (i) at the same dry density, the size of inter-aggregates pores is larger for the coarser crushed material; (ii) mechanical compression only reduces the inter-aggregate porosity in the stress range considered; (iii) the micro-mechanisms governing the flooding under constant-volume condition include the swelling of the clay particles, the increase of the intra-aggregate pores and the collapse of the inter-aggregates pores. The results show a strong effect of the grain size distribution on the hydro-mechanical behaviour and thus the close link between the microstructure and the hydro-mechanical behaviour.
\end{abstract}

Keywords: Compacted crushed argillite; radioactive waste disposal; swelling pressure; microstructure; grain size effect; hydro-mechanical coupling. 


\section{INTRODUCTION}

Deep argillaceous formations are considered as potential host rock for radioactive waste disposal in many countries such as Belgium, Germany, France, Japan and Switzerland. In order to ensure the safety of the whole storage system, it is of prime importance to well understand the involved clay properties on different time scales: during the construction, during the exploitation and during the long term storage life of the waste (Landais \& Aranyossy, 2007). In addition to the coupled thermo-hydro-mechanical behaviour of the host rocks, the engineering properties of backfilling/sealing materials are also an important issue to be investigated because these materials are usually used to avoid preferential pathways for water, gas and radionuclide migration, and they correspond therefore to an important part of the high-level radioactive waste underground repository safety system. In the past decades, bentonites have been widely studied as possible backfilling and sealing materials because of its low permeability, adequate self-sealing potential and high retention capacity (Lloret et al., 2003; Tang \& Cui, 2005; Hoffman et al., 2007). In France, ANDRA (the French Radioactive Waste Management Agency) has been constructing an Underground Research Laboratory (URL) at Bure site (eastern France, at 445-490 m depth) in order to investigate the suitability of the Callovo-Oxfordian (COx) argillaceous formation for the disposal of high-level radioactive waste (Lebon \& Mouroux, 1999). Unlike in the currently well-accepted design using compacted bentonite, the excavated COx argillite has been proposed at this URL as a possible sealing/backfilling material to isolate the waste canisters from the concrete plug and the access galleries. The main advantages of this design are: (i) the recycling of the excavated COx argillite as sealing/backfilling material reduces the negative impact on the environment; (ii) replacing commercial bentonite by excavated COx argillite reduces the cost; (iii) problems related to the mineralogical or physico-chemical incompatibility between the host rock and the engineered barrier can be avoided (Andra, 2005). In addition, a series of tests have been carried out to investigate the geotechnical, hydraulic, mechanical and compaction behavior of the crushed COx argillite. Based on the obtained results, Andra (2005) concluded that the COx argillite is suitable to be used as a sealing/backfilling material.

It is expected that after installation of engineered barriers, water infiltration from the host rock takes place and the compacted argillite will expand and develop swelling pressure under nearly confined conditions. This swelling pressure should be high enough to ensure the sealing effectiveness. On the other hand, the swelling properties of the compacted argillite must be compatible with the in-situ stress state, i.e. the swelling pressure should not excess the in-situ minor principal stress (about $7 \mathrm{MPa}$ at Bure URL) so as to ensure the mechanical stability of the system.

The present work aims at investigating the hydro-mechanical properties of compacted crushed COx argillite. Two crushed materials with different grain size distributions (GSD) were considered, that were obtained by crushing the excavated COx argillite with two different procedures. The compressibility of the two crushed materials was investigated by running one-dimensional compression tests at constant water content $(2.4-2.8 \%)$ with loading-unloading cycles. After compaction, water flooding was carried out under constant volume conditions. The effects on the hydro-mechanical behavior of the axial stresses ap- 
plied and the grain size distributions were identified. Finally, the soil microstructure changes before and after flooding were investigated based on the observations at mercury intrusion porosimetry (MIP) and scanning electron microscopy (SEM).

\section{SOIL STUDIED}

The soil studied was the Callovo-Oxfordian (COx) argillite taken during the construction by excavation of the ANDRA URL of Bure. It contains $40-45 \%$ clay minerals with predominance of illite-smectite interstratified minerals, $30 \%$ carbonates and $25-30 \%$ quartz and feldspar. The in-situ water content is $2.8-8.7 \%$; the bulk density is 2.32 $2.61 \mathrm{Mg} / \mathrm{m}^{3}$ and the specific gravity is 2.70 (Fouché et al., 2004). After Zhang et al. (2007), the swelling pressure of COx argillite reaches $10 \mathrm{MPa}$.

The COx argillite was crushed following two different procedures, leading to two soils: (i) soil A was the coarser one with the maximum grain size of $8 \mathrm{~mm}$; its air-dried water content was $2.8 \%$; (2) soil B was the finer one with the maximum grain size of $0.25 \mathrm{~mm}$; its air-dried water content was $2.4 \%$. To obtain soil A, the excavated COx argillite taken from the underground laboratory was crushed using an industrial crusher to reach its maximum grain size of $8 \mathrm{~mm}$ and then air-dried. For soil B, a small quantity of soil A was then ground using a laboratory crusher to obtain a finer powder (maximum grain size of $0.25 \mathrm{~mm}$ ). The particle size distributions of the two soils determined by dry sieving are presented in Fig. 1. Soil A contains $18 \%$ fine grains $(<0.08 \mathrm{~mm})$ while soil B contains $70 \%$ fine grains. In addition, the grain size distribution was also determined by dry-sieving method after washing (Afnor, 1996) for elements larger than $80 \mu \mathrm{m}$ and by hydrometer method (Afnor, 1992) for elements smaller than $80 \mu \mathrm{m}$. Interestingly, the two curves are similar and show a large fraction of fine grains. More than $95 \%$ grains are smaller than $0.08 \mathrm{~mm}$. This observation constitutes the first illustration of the water content-dependent nature of the compacted crushed argillite: the argillite grains disaggregate when the water content is increasing, giving rise to smaller grains.

\section{EXPERIMENTAL METHODS}

\subsection{Experimental set-up}

Fig. 2 presents the experimental set-up used to study the compaction behaviour and the hydro-mechanical coupling. An oedometer cell (50-mm inner diameter) was placed on the top plate of the displacement shaft, and can moves upwards/downwards together with the displacement shaft. A force transducer was used to monitor the vertical stress $\sigma_{v}$ while a displacement transducer was used to monitor the vertical strain $\varepsilon_{v}$. A volume/pressure controller was connected to the bottom base of the cell for the purpose of water flooding. A porous disc was placed between the specimen and the piston allowing water/air flow from the soil sample through the gap between the piston and the oedometer ring. All data were recorded by a data logging system. Note that the deformation of soil during the test was measured directly by the displacement transducer which was fixed on the piston (Fig. 2). The deformation of the piston and the oedometer cell during compaction was found to be 
negligible. Therefore, the measured displacement by the transducer was directly used to calculate the axial strain of soil specimen.

\subsection{Experiment procedure}

During the compaction, the crushed material was firstly placed inside the oedometer cell. After installation of the piston, the press was manually run to statically compress the soil to an initial dry density $\rho_{d}$ of $1.5 \mathrm{Mg} / \mathrm{m}^{3}$, the corresponding initial height of the sample being $2.67 \mathrm{~cm}$. The compaction was then started at a constant rate of $0.05 \mathrm{~mm} / \mathrm{min}$. At the end of compaction, the axial stress was unloaded to a given value, the specimen was then flooded under constant-volume condition. The constant-volume condition was ensured by fixing the displacement shaft and, if necessary, by manually adjusting it according to the records of the displacement transducer. During flooding, the full saturation of the specimen was checked by using an absorbing paper to check whether free water flows out from the gap between the piston and oedometer ring. Table 1 summarizes the test program.

\subsection{Description of the test program}

For the tests E01, E02, E03, and E04, when $\rho_{d}$ reached $1.7 \mathrm{Mg} / \mathrm{m}^{3}$, the soil was unloaded until $\sigma_{v}$ was equal to $0.5 \mathrm{MPa}$ and then reloaded at the same rate. This unloading/reloading cycle was also repeated at $\rho_{d}$ equal to 1.8 and $1.9 \mathrm{Mg} / \mathrm{m}^{3}$. When $\rho_{d}$ reached $2.0 \mathrm{Mg} / \mathrm{m}^{3}$, the soil was unloaded to $\sigma_{v}$ of 7 or $0.5 \mathrm{MPa}$ prior to flooding under constant-volume conditions by injecting distilled water at a vertical stress of $100 \mathrm{kPa}$. Note that in practice, before the backfilling material is placed in the repository, it is first compacted to a target density. The unloading steps performed in this investigation aims to understand the rebound behavior of the compacted backfilling material. At the end of each loading step, about 1 hour was given to reach apparent equilibrium. The axial strain change was checked by the displacement transducer. The corresponding dry density and void ratio were therefore calculated according to the recorded displacement values during loading/unloading procedures.

For the tests E05 and E06, the soil sample was compacted directly to $\rho_{d}=2.0 \mathrm{Mg} / \mathrm{m}^{3}$ without any loading/unloading cycles, and was flooded following the same procedures that were applied to the tests E01-E04.

For the tests E07 and E08, a procedure similar to that of swell-consolidation test described by Basma et al. (1995) was applied: the initially compacted sample was wetted and allowed to fully swell under a low sitting load. After that a standard consolidation test was conducted by applying incremental loads. The load required to revert the specimen to its initial void ration (or height) is defined as the swelling pressure. The high-pressure load frames described by Marcial et al. (2002) was used in these two tests. The soil was first compacted to $\rho_{d}=2.0 \mathrm{Mg} / \mathrm{m}^{3}$ using the equipment described in Fig. 2. After unloading, the oedometer cell with the compacted specimen was removed to the load frame allowing application of constant $\sigma_{v}$ and monitoring the soil vertical strain. A low $\sigma_{v}$ of $0.1 \mathrm{MPa}$ was firstly applied and then water flooding was carried out. After stabilization of the soil strain, $\sigma_{v}$ was increased in steps to $0.2,0.4,0.9,1.7,3.5,6.9,13.8,27.7$ and $55.3 \mathrm{MPa}$, each loading step having been maintained for $24 \mathrm{~h}$. The same steps were adopted for unloading. Note that this duration is recommended by the French Standard (Afnor, 2005) for strain stabilization. 


\subsection{Microstructural observation}

Soil properties at the microscopic level are directly related to its macroscopic engineering behaviour and physical properties. Basically, measurements and observations at the microstructural level involving clay units and their aggregations and pore size distribution characteristics are very important, since they help better understand the behaviour of the soil under various hydro-mechanical stress state conditions.

In order to analyse the soil microstructure changes during these hydro-mechanical loadings, MIP tests were performed on soil compacted at $\rho_{d}$ equal to 1.8 and $2.0 \mathrm{Mg} / \mathrm{m}^{3}$ following the static compaction procedure (including the unloading steps) described previously. These tests were also performed on soil compacted at $\rho_{d}$ equal to $2.0 \mathrm{Mg} / \mathrm{m}^{3}$ and flooded under constant volume conditions, where the initial applied vertical stress $\sigma_{v}$ was equal to 7 or $0.5 \mathrm{MPa}$. For the purpose of comparison, an additional test was equally performed on intact COx argillite at an initial water content $w=7.0 \%$. In addition, SEM tests were performed on soil samples having $\rho_{d}$ equal to $2.0 \mathrm{Mg} / \mathrm{m}^{3}$ before and after flooding under an initial vertical stress $\sigma_{v}$ equal to 7 or $0.5 \mathrm{MPa}$ at constant volume conditions.

For each MIP and SEM test, two parallel soil samples were prepared by repeating the hydro-mechanical loading in the oedometer cell, and then were rapidly frozen using liquid nitrogen previously vacuum-cooled below its boiling temperature $\left(-196{ }^{\circ} \mathrm{C}\right)$ in order to avoid any boiling during immersion of the sample. Freezing was also accelerated by using small sticks of soil (1-2 g in weight). Finally, the frozen samples were subjected to sublimation in a true vacuum $\left(10^{-2} \mathrm{~mm} \mathrm{Hg}\right)$ so as to eliminate the water without the formation of air-water capillary menisci, which cause volume shrinkage on drying.

During MIP test, the sample is placed in a dilatometer that is put under vacuum. Mercury intrusion was then performed by progressively increasing mercury pressure up to $200 \mathrm{MPa}$. Due to the pressure increase, mercury progressively penetrates into the voids of sample, starting, at lower pressures, with the largest pores and ending up at highest pressures by penetration into the smallest pores that can be reached. The volume of the pores penetrated during the increase in pressure is continuously monitored by a system that follows the decrease of the mercury level in the dilatometer. In this case, blank tests are needed to correct errors associated with the system compressibility and temperature effects (see Delage et al., 2006 for more detail). Prior to the SEM test, the freeze-dried samples were coated with aurum to increase the electric conductivity.

\section{EXPERIMENTAL RESULTS}

\subsection{Compression behaviour}

The variations of $\rho_{d}$ with $\sigma_{\mathrm{v}}$ during the compression of the crushed materials are shown in Fig. 3. The compression curves are similar for each soil: curves E01, E02 and E05 for the coarser soil A and curves E03, E04 and E06 for the finer soil B. A significant difference is however observed between the two soils. The pre-compression stress that corresponds to the pressure required to obtain the initial $\rho_{d}$ of $1.5 \mathrm{Mg} / \mathrm{m}^{3}$ is lower than $0.4 \mathrm{MPa}$ for soil A while that of soil B is close to $2 \mathrm{MPa} . \sigma_{v}$ required to reach $\rho_{d}$ equal to $2.0 \mathrm{Mg} / \mathrm{m}^{3}$ for soil A 
is $27 \mathrm{MPa}$ in test E01, $24 \mathrm{MPa}$ in test $\mathrm{E} 02$ and $37 \mathrm{MPa}$ in test E05, significantly lower than that of soil B: $47 \mathrm{MPa}$ in test E03, $39 \mathrm{MPa}$ in test E04 and $47 \mathrm{MPa}$ in test E06.

In Fig. 4, the results of these tests are presented in the plane of void ratio (e) versus $\log \sigma_{\mathrm{v}}$. During loading, when $\sigma_{\mathrm{v}}$ exceeded the pre-compression stress, e decreased drastically and a clear linear relationship can be observed between e and $\log \sigma_{\mathrm{v}}$. The slope $\mathrm{de} / \mathrm{d} \log \sigma_{\mathrm{v}}$ corresponds to the compression index at the initial water content, $\mathrm{C}_{\text {cwi }}$. For soil $\mathrm{A}, \mathrm{C}_{\mathrm{cwi}}$ is equal to 0.238 for E01, 0.240 for E02 and 0.229 for E05. Larger values were obtained for soil $\mathrm{B}: \mathrm{C}_{\mathrm{cwi}}$ is equal to 0.316 for E03, 0.317 for E04 and 0.384 for E06.

In a similar fashion, the swelling index at the initial water content, $C_{s w i}$, was determined that corresponds to the slope $-\mathrm{d} e / \mathrm{d} \log \sigma_{v}$ on the unloading paths. This operation was done for different $\rho_{d}$ values: $1.7,1.8,1.9$ and $2.0 \mathrm{Mg} / \mathrm{m}^{3}$. In Fig. 5 , the variations of $C_{s w i}$ versus $\rho_{d}$ are plotted for tests E01, E02, E03 and E04. The results show that $C_{s w i}$ increases almost linearly with $\rho_{d}$. The difference between the two soils is not clear. Compared to $C_{c w i}, C_{s w i}$ seems to be of one order of magnitude smaller.

\subsection{Hydro-mechanical behaviour}

After compaction to $\rho_{d}$ equal to $2.0 \mathrm{Mg} / \mathrm{m}^{3}$, the soil was unloaded to $\sigma_{v}$ equal to 0.5 or $7 \mathrm{MPa}$, and the final dry density was in the range of $1.98-1.99 \mathrm{Mg} / \mathrm{m}^{3}$. The displacement shaft was then blocked and distilled water was subsequently injected at a pressure of 100 $\mathrm{kPa}$ from the bottom of the oedometer cell. Fig. 6 presents the changes of $\sigma_{v}$ and $e$ versus time $(t)$ during water flooding. Note that even though the "constant-volume" conditions were imposed by fixing the displacement shaft, slight changes in soil volume were recorded by the displacement transducer because of the deformability of the system (connection between the load cell and the piston, the soil specimen, the base of the oedometer cell, etc., see Fig. 2).

For test E01, flooding the soil A decreased the vertical stress $\sigma_{v}$ from $7.4 \mathrm{MPa}$ to $5.3 \mathrm{MPa}$ after $120 \mathrm{~h}$ (Fig. $6 a$ ). A slight decrease of $e$ was equally observed, from 0.364 to 0.360 , which corresponds to a volumetric strain of $0.3 \%$. In tests E03 and E06, soil B was equally flooded at high $\sigma_{v}$ (7.6 MPa for E03, Fig. $6 b$; and 8.0 MPa for E06, Fig. $6 c$ ). The results obtained from the two tests were similar: $\sigma_{v}$ decreased, then increased and finally decreased to reach a stabilization value of $7.2 \mathrm{MPa}$; the changes of $e$ were in the same fashion as $\sigma_{v}$ changes. The final volumetric strain was small, less than $0.15 \%$. Compared to soil A, soil B had a higher final $\sigma_{v}$ after water flooding.

For tests E02, E04, and E05, the soil specimens were flooded under lower $\sigma_{v}$. In the test E02, due to the failure of volume control, the results were not presented. A similar procedure was then applied in test E05, the results were presented in Fig. $6 e$. It can be seen that flooding soil A resulted in a quick increase of $\sigma_{v}$ from the initial value of $0.69 \mathrm{MPa}$ to an equilibrium value of $4.23 \mathrm{MPa}$ after $20 \mathrm{~h}$. A slight variation of $e$ was also observed and the corresponding volumetric strain is lower than $0.15 \%$. In test E04, water flooding was performed on soil B. The results show a quick increase of $\sigma_{v}$ in the beginning (Fig. $6 d$ ); $e$ increased from 0.369 to 0.371 after $6 \mathrm{~h}$. A manual adjustment was done at this moment to bring the void ratio $e$ back to its initial value. After $50 \mathrm{~h}, e$ was equal to 0.367 and $\sigma_{v}$ was 
equal to $5.08 \mathrm{MPa}$. Compared to soil A flooded at low stress, soil B showed a higher final stress: 5.08 MPa against 4.23 $\mathrm{MPa}(\mathrm{E} 05)$.

The results of oedometer tests E07 (soil A) and E08 (soil B) are presented in Fig. 7. The soil was firstly compacted at $\rho_{d}$ equal to $2.0 \mathrm{Mg} / \mathrm{m}^{3}$ following the same procedure of tests E05 and E06. After compaction, the cell was put in an oedometer frame to perform swellconsolidation tests. Fig. $7 a$ presents changes in void ratio $e$ versus time. An initial $\sigma_{v}$ of $0.1 \mathrm{MPa}$ was first applied prior to water flooding. Swelling was observed in the two tests: $e$ increased from 0.350 to 0.442 for test E07 (soil A, after $100 \mathrm{~h}$ ) and to 0.503 for test E08 (soil B, after $300 \mathrm{~h}$ ). When the swelling stabilized, subsequent loading/unloading steps were applied, each step having been maintained for $24 \mathrm{~h}$ (this duration appeared to be sufficient for the stabilisation). In Fig. 7b, the values of $e$ at equilibrium are plotted versus the logarithm of $\sigma_{v}$. The compressibility parameters were determined from these curves: for soil A, the compression index $C_{c}$ and the swelling index $C_{s}$ are respectively equal to 0.172 and 0.082; for soil B, $C_{c}$ and $C_{s}$ are respectively equal to 0.164 and 0.075. After Basma et al. (1995), this test can be also used to determine the soil swelling pressure that is considered as the vertical stress required to bring the void ratio back to its initial value. As shown in Fig. $7 b$, a swelling pressure of $2.5 \mathrm{MPa}$ was obtained for soil A (E07), and 5.0 MPa for soil B (E08).

\subsection{Mercury intrusion porosimetry}

Before presenting the results from the mercury intrusion porosimetry investigations, the different clay microstructural levels and the corresponding terminologies considered in this study are first introduced. The description is based on that given by Delage et al. (2006), where various clay microstructural levels were summarized in detail. In a compacted unsaturated soil, clay particles (made up of stacked clay layers) are aggregated together to form a typical aggregate structure (also termed as double structure). In this structure, various levels of porosity can be indentified:

(i) planar interlayer spaces between the clay layers inside the clay particles, interpreted as inter-layer or intra-particle pores;

(ii) small voids between clay particles inside the aggregates, interpreted as inter-particle or intra-aggregate pores;

(iii) large voids between the aggregates made up of clay particles, interpreted as interaggregate pores.

Fig. 8 presents the results of MIP tests obtained on soil A and on the intact COx argillite . The intruded mercury void ratio $\left(e_{m}\right)$ was defined as the ratio of mercury intrusion volume $V_{\mathrm{m}}$ to soil solid volume $V_{\mathrm{s}}$ :

$$
e_{m}=\frac{V_{m}}{V_{s}}
$$

The pore entrance diameter $(d)$ was determined from the intrusion pressure $p$ by assuming a cylindrical pore shape:

$$
d=\frac{4 \sigma \cos \theta}{p}
$$


where $\sigma=0.484 \mathrm{~N} / \mathrm{m}$ is the mercury-solid interfacial tension and $\theta=141.3^{\circ}$ is the mercury-solid contact angle (see Delage et al., 2006 for more detail). It can be noted from the $e_{m}-\log d$ plot (Fig. $8 a$ ) that the final values of $e_{m}$ are slightly lower than the values of $e$. This can be mainly explained by the limited range that the MIP technique can cover, i.e. from 0.008 to $15 \mu \mathrm{m}$ (corresponding to the range of $p$ from $200 \mathrm{MPa}$ to $0.1 \mathrm{MPa}$ ); the value of $e_{m}$ does not include the pores larger than $15 \mu \mathrm{m}$ (which may exist in the sample compacted at $\rho_{d}$ equals $1.8 \mathrm{Mg} / \mathrm{m}^{3}, e$ equals 0.50 ) and the pores smaller than $0.008 \mu \mathrm{m}$.

The pore size distribution curves, $\mathrm{d} e_{m} / \mathrm{d} \log (d)$ versus $\log d$, allow the analysis of the soil microstructure. For the intact argillite sample, only a population of intra-aggregate pores having a diameter $d$ close to $0.05 \mu \mathrm{m}$ was observed (Fig. 8f). On the contrary, for the samples of soil A, two populations of pores were observed: intra-aggregate pores that are smaller than $0.1 \mu \mathrm{m}$ and inter-aggregates pores lager than $0.1 \mu \mathrm{m}$. For the soil sample compacted at $\rho_{d}$ equal to $1.8 \mathrm{Mg} / \mathrm{m}^{3}$ ( $e$ equal to 0.50 ), the population of inter-aggregates pores was close to $3 \mu \mathrm{m}$ while that of intra-aggregate pores was close to $0.03 \mu \mathrm{m}$ (Fig. $8 b$ ). For the sample compacted at $\rho_{d}$ equal to $2.0 \mathrm{Mg} / \mathrm{m}^{3}$ ( $e$ equal to 0.35 ), the population of inter-aggregates pores moved leftwards to $1.5 \mu \mathrm{m}$ while that of intra-aggregate pores did not change (Fig. 8c). Subsequent flooding under constant-volume conditions (Fig. 8d,e) decreased the modal size of inter-aggregates pores to $0.3-0.4 \mu \mathrm{m}$, the changes in intraaggregate pores size having been not significant. Fig. $8 d$ shows that flooding under high stresses (initial $\sigma_{\mathrm{v}}$ equal to $7 \mathrm{MPa}$ ) created larger intra-aggregate pores whose size reached $0.05 \mu \mathrm{m}$.

The results obtained from soil B and from the intact COx argillite are presented in Fig. 9. As observed previously on soil A, the values of $e_{m}$ for soil B were slightly lower than the values of $e$. The pore size distribution curve, $\mathrm{d} e_{m} / \mathrm{d} \log (d)$ versus $\log d$, of soil B compacted at $\rho_{d}$ equal to $1.8 \mathrm{Mg} / \mathrm{m}^{3}$ ( $e$ equal to 0.50 ) shows a clear population of inter-aggregates pores of $0.7 \mu \mathrm{m}$ (Fig. $9 \mathrm{~b}$ ). The population of intra-aggregate pores observed previously on soil A was no longer observed on soil B. Fig. $9 c$ shows that compaction at $\rho_{d}$ equal to $2.0 \mathrm{~g} / \mathrm{m}^{3}$ ( $e$ equal to 0.35 ) decreased the size of the population of inter-aggregates pores to $0.4 \mu \mathrm{m}$. Subsequent flooding under constant-volume conditions at high stresses (initial $\sigma_{\mathrm{v}}$ equal to $7 \mathrm{MPa}$, Fig. 9d) slightly decreased the size of the inter-aggregates pores population to $0.3 \mu \mathrm{m}$. At low stresses (initial $\sigma_{\mathrm{v}}$ equals $0.5 \mathrm{MPa}$, Fig. $9 e$ ), this decrease of the population size of inter-aggregates pores when flooding was found to be not significant.

\subsection{Scanning electron microscope}

SEM tests were performed on the soil samples compacted at $\rho_{d}$ equal to $2.0 \mathrm{Mg} / \mathrm{m}^{3}$ before and after flooding at 0.5 and $7 \mathrm{MPa}$ vertical stresses. The pictures were taken on two scales and presented in Fig. $10(125 \times 100 \mu \mathrm{m})$ and Fig. $11(25 \times 20 \mu \mathrm{m})$, respectively.

Fig. $10 a$ shows that the compacted sample of soil A was constituted of several clay aggregates. The size of the aggregates varies from about $1 \mu \mathrm{m}$ to larger than $10 \mu \mathrm{m}$. Note that the aggregates larger than $100 \mu \mathrm{m}$ could not be observed with this magnification (the size of picture taken is $125 \times 100 \mu \mathrm{m}$ ). Inter-aggregates pores larger than $2 \mu \mathrm{m}$ were obvious in this figure. The aggregate circled in Fig. $10 a$ is enlarged in Fig. 11a, showing that it is made up of clay particles of about $1 \mu \mathrm{m}$ in diameter. 
The microstructure of soil A changed completely after flooding under constant-volume conditions (Fig. 10c,e): clay aggregates and large inter-aggregate pores were no longer clearly observed; only small inter-aggregate pores (smaller than $1 \mu \mathrm{m}$ ) were observed in Fig. 10e. The enlargement of these soil samples (Fig. 11c,e) shows that the clay particles were relatively more separate than before.

In case of soil B (Fig. 10b), several clay aggregates smaller than $10 \mu \mathrm{m}$ were observed. The sizes of inter-aggregates pores were not apparent at this magnification (size of picture: $125 \times 100 \mu \mathrm{m}$ ). At a higher magnification (Fig. $11 \mathrm{~b}$, size of picture $25 \times 20 \mu \mathrm{m}$ ), several inter-aggregates pores smaller than $1 \mu \mathrm{m}$ can be observed. The structure of clay aggregates formed by clay particles is also clear in Fig. $11 b$. After flooding, Fig. $10 d$ and Fig. $10 f$ show that the clay particles of soil B are more separate than before. Inter-aggregates pores smaller than $1 \mu \mathrm{m}$ can be observed at a higher magnification (Fig. 11f, size of picture $25 \times 20 \mu \mathrm{m})$.

\section{DISCUSSION}

Two crushed materials, A and B, crushed from the same COx argillite were studied in the present work. The grain size distribution curves determined by dry sieving show that soil A was coarser than soil B (Fig. 1). The results presented in Fig. 3 evidence that the compression behaviour of the crushed material was strongly affected by the grain size distribution. For instance, the vertical stress $\sigma_{v}$ required to reach the initial dry density $\rho_{d}$ of $1.5 \mathrm{Mg} / \mathrm{m}^{3}$ was higher for the finer soil: $\sigma_{v}=2 \mathrm{MPa}$ for soil B against $\sigma_{v}=0.4 \mathrm{MPa}$ for soil A. Furthermore, the vertical stress $\sigma_{v}$ required to reach the final dry density $\rho_{d}$ of $2.0 \mathrm{Mg} / \mathrm{m}^{3}$ was also higher for the finer soil: $\sigma_{v}=39-47 \mathrm{MPa}$ for soil B against $\sigma_{v}=24-37 \mathrm{MPa}$ for soil A. These results are in agreement with the observations by Attom et al. (2001), Omar et al. (2003) and Ferber et al. (2008), showing that the dry density of a finer soil at standard Proctor optimum is lower. Moreover, Tien et al. (2004) studied the static compaction properties of various bentonite-sand mixtures and equally found that the compaction stress required to reach to same dry density was higher with higher bentonite weight ratios. This effect of grain size distribution on the compaction behaviour can be explained by the interactions between the soil grains at contact points in terms of friction and cohesion: the number of contact points being larger for the finer soil, a higher energy is needed to reach a considered density.

The results shown in Fig. 4 evidence that the compression index at initial water content $C_{c w i}$ of the finer soil (soil B) is larger than that of soil A. Similar effect of the soil structure on $C_{c w i}$ was equally observed by Smith et al. (1997) and Imhoff et al. (2004). In the present work, at low stresses, the finer soil $\mathrm{B}$ had higher void ratio; for instance, at $\sigma_{v}$ of $2 \mathrm{MPa}, e$ is equal to 0.8 for soil $\mathrm{B}$ and 0.6 for soil $\mathrm{A}$. This difference is closely related to the original structures of the two soils: assuming that the clay grains kept similar structure to that of intact COx argillite whose dry density is estimated at $2.25 \mathrm{Mg} / \mathrm{m}^{3}$, as soil B was crushed to smaller grain size $(<0.025 \mu \mathrm{m})$ than soil $\mathrm{A}$, when the same mass of soil was put in oedometer cell for compaction, the finer soil B must be looser with a larger initial void ratio, thus a higher compressibility. Under loading, the effect of the soil initial structure is progressively suppressed and the two compression curves tend to merge. Note that Tang et al. (2009) in- 
vestigated the compression behaviour of soil $\mathrm{A}$ in the same manner, and found that the compression index decreased when the sample was saturated.

Unloading/reloading cycles applied at various $\rho_{d}$ showed that the swelling index at constant water content $\left(C_{s w i}\right)$ increased with $\rho_{d}$. As this parameter depends mainly on the compressibility of soil aggregates (Tang et al., 2008), this increase of $C_{s w i}$ can be explained by the creation of micro-cracks by compression stresses on the soil aggregates which results in a decrease in rigidity (Wright $e t$ al., 2001). That explains equally why $C_{s w i}$ was almost independent of the grain size distribution.

It is commonly accepted that hydration initially occurred in the hydrophilic zone of the clay, i.e. on the mineral surface and around the exchangeable cations in the interlayer spaces inside the clay aggregates. After Saiyouri et al. (2000), the clay particles with a number of stacked clay layers are divided, when hydrated, into thinner ones that are made up of a smaller number of stacked layers. This is in agreement with the results presented in Fig. 1, which clearly show the decrease of the size of clay aggregates after soaking with water. The pictures obtained from SEM tests (Fig. 10 and Fig. 11) confirm that flooding separated the clay particles from the clay aggregates.

It has been observed that flooding compacted soils at constant-volume conditions induced a decrease of $\sigma_{v}$ when the initial $\sigma_{v}$ was high (7 MPa) and an increase of $\sigma_{v}$ when the initial $\sigma_{v}$ was low $(0.5 \mathrm{MPa})$. The changes in swelling pressure of compacted expansive soils upon wetting under constant-volume conditions were also studied by Komine \& Ogata (1999) and Lloret et al. (2003), and similar observations were made. The observed phenomenon can be explained based on the double-structure model described by Gens \& Alonso (1992), Alonso et al. (1999) and Sanchez et al. (2005), Tang and Cui (2009). On the one hand, wetting increases the interlayer distance (between clay particles) resulting in swelling of clay aggregates. On the other hand, this decreases the mechanical resistance of the structure. As a consequence, swelling of the clay aggregates induces an increase of confining stresses when the soil is wetted under constant-volume conditions at low initial stresses. On the contrary, when the soil is wetted under constant-volume conditions but at high initial stresses, wetting induces collapse of inter-aggregates pores and thus decrease of the confining stresses. The flooding-induced collapse of inter-aggregates pores was also evidenced by the MIP tests: the results in Fig. 8 and Fig. 9 show a decrease in size of the inter-aggregates pores population after flooding. The SEM pictures in Figs. 10 and 11 also illustrate these mechanisms.

Microstructural investigations show that the initial vertical stress has a negligible effect on the microstructure of the soil after flooding. Actually, flooding the sample at low initial stresses (under constant-volume conditions) increases the vertical stress on one hand and decreases the yield stress (mechanical weakening) on the other hand. The collapse of interaggregates pores takes place when the vertical stress reaches the yield stress. As a result, event though flooding the sample under 0.5 or $7 \mathrm{MPa}$ led to different responses in terms of vertical stresses, the consequences from the microstructural point of view are the same: collapse of inter-aggregates pores.

Imbert and Villar (2006) also performed flooding tests in the oedometer cell under constant-volume conditions in order to monitor the swelling pressure of a bentonite pellets/powder mixture. Tests showed a common swelling pressure development pattern: an initial peak followed by a decrease of swelling pressure that eventually increased again. Maugis and Imbert (2007) performed a numerical analysis of these tests by using of the 
Barcelona basic model (BBM, see in Alonso et al., 1990) in order to interpret these results. The authors explained the swelling pressure variations, specially its decrease, by the yield stress decrease. This can be also used to explain the results obtained in tests E03 and E06 where the vertical stress (initially high) subsequently decreased, increased, and then decreased to reach stabilization (Fig. 6).

It has been observed that flooding the finer soil under constant-volume conditions at the initial $\sigma_{v}$ of $0.5 \mathrm{MPa}$ induced a higher final value of $\sigma_{v}$ (for soil $\mathrm{B}, \sigma_{v}$ equal to $5.08 \mathrm{MPa}$, test E04; for soil A, it equals 4.23 MPa for test E05; see Fig. 6). On the other hand, flooding the finer soil under constant-volume conditions at the initial $\sigma_{v}$ of $7 \mathrm{MPa}$ equally induced a higher final value of $\sigma_{v}$ (for soil $\mathrm{B}, \sigma_{v}$ equals 7.2 $\mathrm{MPa}$, tests E03 and E06; for soil $\mathrm{A}$, it equals $5.3 \mathrm{MPa}$, test E01). Furthermore, the swelling pressure determined by the swell-consolidation method was equally higher for the finer soil (Fig. 7b, 5.0 MPa for soil $\mathrm{B}, \mathrm{E} 08 ; 2.5 \mathrm{MPa}$ for soil A, E07). It can be then concluded that the finer soil has a higher swelling potential than the coarser one. This effect of the grain size distribution may be explained by the following mechanisms: when crushing the argillite to a finer material, the initial structure of illite-smectite interstratified clay minerals may be more destructured and hence give more spaces for water penetration, increasing the swelling potential.

However, it should be noted that, for a given soil, different methods represent different boundary conditions and can lead to different swelling pressures. For example, the swellconsolidation method can give higher swelling pressure than other methods in which the material is kept in a constant volume cell (Al-Shamrani and Dhowian, 2003). From a practical point of view, the boundary conditions of the backfilling material in the repository are highly complicated (Siemens and Blatz, 2009), choosing an appropriate swelling testing technique to simulate the field conditions is essential for the design. In the present study, only two typical boundary conditions were considered, and further systematic investigation on the swelling pressure and the coupled hydro-mechanical behaviour of COx argillite will be carried in the next stage of the study.

MIP tests are usually performed to analyse the microstructure changes upon mechanical loading (Delage \& Lefebvre, 1984; Lloret et al., 2003; Romero et al., 2003; Hoffmann et al., 2007; Tarantino \& De Col, 2008). But this method usually results in underestimation of porosity due to the bottle neck effect (Romero and Simms, 2008). It has been observed that the decrease of soil porosity during compaction is mainly attributed to the decrease in the size of inter-aggregates pores. This is in agreement with the results obtained in the present work (Fig. 8 and Fig. 9). As far as the microstructure changes upon wetting, few works have been carried out. Cui et al. (2002) analysed the microstructure changes of compacted expansive soil during wetting under constant-volume conditions. The results clearly show the decrease in inter-aggregates pores size with decrease in soil suction. Ferber et al. (2008) performed MIP tests on a compacted silty clay and a compacted high-plasticity clay subjected to flooding under a constant vertical stress $\sigma_{\mathrm{v}}$ of 3 and $200 \mathrm{kPa}$. The results show that, for the silty clay, wetting induced collapse of inter-aggregates pores but did not affect the intra-aggregate pores. Nevertheless, for the high-plasticity clay, wetting induced not only the collapse of inter-aggregates pores but also the swelling of intra-aggregate pores.

Flooding resulted in inter-aggregates pores size decrease for both soil A and soil B. On the other hand, intra-aggregate pores were only observed on soil A; for the finer soil B, this population of intra-aggregate pores would be hidden by inter-aggregates pores having similar size because of the large amount of fine grains created during crushing. For soil A, 
the intra-aggregate pores was not influenced by the compaction; its size changed slightly after flooding. As explained previously, the size of intra-aggregate pores is closely related to the distance between the clay particles and thus to the clay water content, $w$. For the intact soil sample having $w$ equal to $7 \%$, the intra-aggregate pores population was close to $0.05 \mu \mathrm{m}$ (Fig. $8 f$ and Fig. 9f). Fouché et al. (2004) also obtained an intra-aggregate pore population at $0.05 \mu \mathrm{m}$ on an intact $\mathrm{COx}$ argillite sample freeze-dried from an initial water content $w$ equal to $7.2 \%$. For the compacted soil sample before flooding, it was air-dried and the water content was lower $(2.4 \%$ for soil B and $2.8 \%$ for soil A). The intraaggregate pores size observed was close to $0.03 \mu \mathrm{m}$, which is little smaller than that of the intact sample $(0.05 \mu \mathrm{m})$. These results are similar to that observed by other authors on oven-dried COx argillite: Sammartino et al. (2003) identified a population of intraaggregate pores at $0.02 \mu \mathrm{m}$ on samples oven-dried at $105^{\circ} \mathrm{C}$; Boulin et al. (2008) also observed an intra-aggregate pore population at $0.02 \mu \mathrm{m}$ on samples oven-dried at $70{ }^{\circ} \mathrm{C}$ for one week. It indicates that the decrease of water content can result in volume shrinkage and decreasing of intra-aggregate pores size. Note however that the water content of the compacted sample at $\rho_{d}$ equal to $2.0 \mathrm{Mg} / \mathrm{m}^{3}$ after water flooding was $13 \%$, much higher than that of the intact COx argillite, showing likely that water content is not a direct indicator of the intra-aggregate pore population. This slight effect of water flooding on the size of intraaggregate pores can be explained by the following two mechanisms:

(i) the swelling of the soil particles was confined under constant-volume conditions, the increase of the intra-aggregate pore sizes may be minimized. As suggested by Saiyouri et al. (1998), the constant volume condition does not allow the clay layer to absorb more than two layers of water. However, it should be noted that different results were obtained by Devineau et al. (2006) and Villar (2007). In the test of Devineau et al. (2006), they found that the confined bentonite reached a three-layer hydrate under high relative humidity $(R H=98 \%)$. The results of Villar (2007) indicated that the interlayer swelling is not hindered by external confinement. Differences of findings on the effect of confinement on soil hydration may derive from different test conditions, methods and materials.

(ii) the flooding duration (50-120 hours) was probably not long enough for the water entering inside the clay particles, since the permeability of COx argillite is quite low: $10^{-21} \mathrm{~m}^{2}$ after Homand et al., (2004). Delage et al. (2006) observed that the microstructure of compacted expansive clay was still changing after 90 days under constant-volume conditions.

The microstructure changes of compacted soils during wetting have been observed on SEM by Cui et al. (2002) and Komine \& Ogata (1999): wetting induced separation of clay particles from the aggregates and as a result, filling of inter-aggregates pores. This interaggregates pores clogging can lead to a decrease in soil permeability (Cui et al. 2008, Ye et al. 2009). This is consistent with the observation made in the present work (see Fig. 10 and Fig. 11). Using the Environmental Scanning Electron Microscope (ESEM), Montes et al. (2004) evidenced the swelling and the disaggregation of clay aggregates when wetting the COx argillite. The SEM pictures presented by Boulin et al. (2008), Fouché et al. (2004) and Wright et al. (2001) on intact COx argillite show a intra-aggregate pores size comprised between 0.02 and $0.1 \mu \mathrm{m}$; that is in agreement with the MIP results obtained in this study (see Fig. $8 f$ and Fig. 9f).

The comparison between the SEM pictures after water flooding for the two soils (A and B) show that there is no significant difference between them (see Fig. 10 and Fig. $11 c, d, e$, 
f). MIP tests also show similar soil structures (see Fig. 8 and Fig. $9 d, e$ ). The compression indexes $\left(\mathrm{C}_{\mathrm{c}}\right.$ and $\left.\mathrm{C}_{\mathrm{s}}\right)$ at saturated state are also similar for the two soils (Fig. 7), showing that the effect of grain size distribution of crushed soils was minimized after water flooding because of the disaggregation of clay aggregates. This is in agreement with the observation of complete disaggregation of clay aggregates after soaking shown in Fig. 1. Note also that the results in Fig. 1 were obtained after soaking the soil in water using dispersing agent while the results in Fig. 7 were obtained by soaking the soil in the oedometer cell. This can explain why the results in Fig. 1 of the two samples are similar while those in Fig. 7 are different.

\section{CONCLUSIONS}

Compacted crushed COx argillite has been considered as a possible sealing/backfilling material in deep radioactive waste disposal in France. The hydro-mechanical behaviour of the samples compacted from two crushed materials of the COx argillite has been investigated by performing uniaxial compression tests. The two crushed materials have different grain size distributions. The microstructure changes of the samples under different test conditions were characterized through MIP and SEM observations.

Uniaxial compression tests to a dry density of $2.0 \mathrm{Mg} / \mathrm{m}^{3}$ showed that the compression curves were strongly dependent on the grain size distribution: (i) higher stresses were needed for the finer crushed material to reach the same dry density; (ii) the compression index at the initial water content $C_{\text {cwi }}$ of the finer soil was larger. In addition, the swelling index at the initial water content $C_{\mathrm{swi}}$ increased with the dry density and seemed to be independent of the grain size distribution.

The effect of the grain size distribution on the hydro-mechanical behaviour was also observed; the finer soil exhibited higher swelling potential when water flooded: (i) water flooding under constant-volume conditions under a low initial vertical stress of $0.5 \mathrm{MPa}$ induced a final vertical stress of $4 \mathrm{MPa}$ for the coarser soil (soil A) and $5 \mathrm{MPa}$ for the finer soil (soil B); (ii) water flooding under constant-volume conditions under a high initial vertical stress of $7 \mathrm{MPa}$ induced either swelling or collapse. The final vertical stress was equal to $5 \mathrm{MPa}$ for the coarser soil and $7 \mathrm{MPa}$ for the finer soil. (iii) the swelling pressure determined following the swell-consolidation procedure on the finer soil is equal to $5 \mathrm{MPa}$, i.e. twice that of the coarser soil $(2.5 \mathrm{MPa})$. From a practical point of view, the swelling pressures of the finer crushed material (soil B) are high enough to ensure the backfill and seal function and low enough $(<7 \mathrm{MPa})$ to avoid any damage to the host-rock.

The MIP tests performed show that the soil volume changes during compaction was mainly due to the decrease of the sizes of inter-aggregate pores. Water flooding under constant-volume conditions also induced decrease in the sizes of inter-aggregates pores. SEM observations performed on the samples before and after water flooding show that water flooding separated the clay particles from the aggregates. The decrease in inter-aggregates pores size can be related to both the collapse of the aggregated-structure under mechanical stresses and the filling of clay particles separated from hydrated aggregates. 


\section{ACKNOWLEDGEMENTS}

The authors wish to acknowledge ANDRA (the French Radioactive Waste Management Agency) for its financial support. The views expressed in this paper are that of the authors and do not engage ANDRA in any matter.

\section{REFERENCES}

Afnor (1992). Soil investigation and testing - Granulometric analysis - Hydrometer method. French standard. NF P 94-057. (in French).

Afnor (1996). Soil investigation and testing - Granulometric analysis - Dry sieving method after washing. French standard. NF P 94-056. (in French).

Afnor (2005). Geotechnical investigating and testing, Laboratory testing of soils, Part 5: Incremental loading odometer test. French standard. XP CEN ISO/TS 17892-5.

Alonso, E.E., Vaunat, J. \& Gens, A. (1999). Modelling the mechanical behaviour of expansive clays. Engineering Geology 54, No. 1-2, 173-183.

Al-Shamrani, M.A., Dhowian, A.W. (2003). Experimental study of lateral restraint effects on the potential heave of expansive soils. Engineering Geology 69, 63-81.

Andra (2005). Référentiel des matériaux d'un stockage de déchets à haute activité et à vie longue Tome 4: Les matériaux à base d'argilites excavées et remaniées. Rapport Andra $\mathrm{n}^{\circ}$ CRPASCM040015B.

Attom, M.F., Abu-Zreig, M.M. \& Obaidat, M.T. (2001). Changes in clay swelling and shear strength properties with different sample preparation techniques. Geotechnical Testing Journal 24, No. 2, 157-163.

Basma, A.A., Al-Homoud, A.S. \& Husein, A. (1995). Laboratory assessment of swelling pressure of expansive soils. Applied Clay Science 9, No. 5, 355-368.

Boulin, P.F., Angulo-Jaramillo, R., Daian, J.F., Talandier, J. \& Berne, P. (2008). Pore gas connectivity analysis in Callovo-Oxfordian argillite. Applied Clay Science 42, No. 1-2, 276-283.

Cui, Y.J., Loiseau, C. \& Delage, P. Microstructure changes of a confined swelling soil due to suction controlled hydration. Unsaturated Soils. Proc. 3rd Int. Conf. on Unsaturated Soils (UNSAT 2002), Recife, Brazil (ed. Jucá, J.F.T., de Campos, T.M.P. and Marinho, F.A.M.), Lisse: Swets \& Zeitlinger, Vol. 2, pp. 593-598.

Cui Y.J., Tang A.M., Loiseau C. \& Delage P. (2008). Determining the unsaturated hydraulic conductivity of a compacted sand-bentonite under constant-volume and free-swell conditions. Physics and Chemistry of the Earth 33, Supplement 1, S462-S471.

Delage, P., \& Lefebvre, G. (1984). Study of the structure of a sensitive Champlain clay and of its evolution during consolidation. Canadian Geotechnical Journal 21, No. 1, 2135 .

Delage, P., Marcial, D., Cui, Y.J. \& Ruiz, X. (2006). Ageing effects in a compacted bentonite:a microstructure approach, Géotechnique 56, No. 5, 291-304.

Devineau, K., Bihannic, I., Michot, L., Villiéras, F., Masrouri, F., Cuisinier, O., Fragneto, G. and Michau, N. (2006) In situ neutron diffraction analysis of the influence of geomet- 
ric confinement on crystalline swelling of montmorillonite. Applied Clay Science, 31, 76-84.

Ferber, V., Auriol, J.C., Cui, Y.J. \& Magnan, J.P. (2008). Wetting-induced volume changes in compacted silty clays and high-plasticity clays. Canadian Geotechnical Journal 45, No. 2, 252-265.

Fouché, O., Wright, H., Le Cléac'h, J.M. \& Pellenard, P. (2004). Fabric control on strain and rupture of heterogeneous shale samples by using a non-conventional mechanical test. Applied Clay Science 26, No. 1-4, 367-387.

Gens, A. \& Alonso, E.E. (1992). A framework for the behaviour of unsaturated expansive clays. Canadian Geotechnical Journal 29, No. 6, 1013-1032.

Hoffmann C., Alonso E.E. \& Romero E. (2007). Hydro-mechanical behaviour of bentonite pellet mixtures. Physics and Chemistry of the Earth 32, No. 8-14, 832-849.

Homand, F., Giraud, A., Edcoffier, S., Koriche, A. \& Hoxha, D. (2004). Permeability determination of a deep argillite in saturated and partially saturated conditions. International Journal of Heat and Mass Transfer 47, No. 14-16, 3517-3531.

Imbert, C. \& Villar, M.V. (2006). Hydro-mechanical response of a bentonite pellets/powder mixture upon infiltration. Applied Clay Science 32, Nos. 3-4, 197-209.

Imhoff, S., da Silva, A.P. \& Fallow, D. (2004). Susceptibility to compaction, load support capacity, and soil compressibility of Hapludox. Soil Sci. Soc. Am. J. 68, No. 1, 17-24.

Komine, H. \& Ogata, N. (1999). Experimental study on swelling characteristics of sandbentonite mixture for nuclear waste disposal. Soils and Foundations 39, No. 2, 83-97.

Landais, P. \& Aranyossy, J.F. (2007). Clays in natural \& engineering barriers for radioactive waste confinement. Physics and Chemistry of the earth 32, No. 8-14, 1.

Lebon, P. \& Mouroux, B. (1999). Knowledge of the three French underground laboratory sites. Engineering Geology 52, No. 3-4, 251-256.

Lloret, A., Villar, M.V., Sanchez, M., Gens, A., Pintado, X. \& Alonso, E.E. (2003). Mechnical behaviour of heavily compacted bentonite under high suction changes. Géotechnique 53, No. 1, 27-40.

Marcial, D., Delage, P. \& Cui, Y.J. (2002). On the high stress compression of bentonites. Canadian Geotechnical Journal 39, No. 4, 812-820.

Montes, H.G., Duplay, J., Martinez, L., Escoffier, S. \& Rousset, D. (2004). Structural modifications of Callovo-Oxfordian argillite under hydration.dehydration conditions. Applied Clay Science 25, No. 3-4, 187-194.

Omar, M., Shanableh, A., Basma, A. \& Barakat, S. (2003). Compaction characteristics of granular soils in United Arab Emirates. Geotechnical and Geological Engineering 21, No. 3, 283-295.

Romero, E., Gens, A. \& Lloret, A. (2003). Suction effects on a compacted clay under nonisothermal conditions. Géotechnique 53, No. 1, 65-81.

Romero, E., Simms, P.H. (2008). Microstructure investigation in unsaturated soils: a review with special attention to contribution of mercury intrusion porosimetry and environmental scanning electron microscopy. Geotech. Geol. Eng. 26:705-727.

Saiyouri, N., Hicher, P.Y. \& Tessier, D. (1998). Microstructural analysis of highly compacted clay swelling. Proc. $2^{\text {nd }}$ Int. Conf. on Unsaturated soils, Beijing: Academic publishers, Vol. 1: pp. 119-124. 
Saiyouri, N., Hicher, P.Y. \& Tessier, D. (2000). Microstructural approach and transfer water modeling in highly compacted unsaturated swelling clays. Mech. Cohesive Frictional Mater 5, No. 1, 41-60.

Sammartino, S., Bouchet, A., Prêt, D., Parneix, J.C. \& Tevissen, E. (2003). Spatial distribution of porosity and minerals in clay rocks from the Callovo-Oxfordian formation (Meuse/Haute-Marne, Eastern France) - implications on ionics species diffusion and rock sorption capability. Applied Clay Science 23, No. 1-4, 157-166.

Sanchez, M., Gens, A., Guimaraes, L.N. \& Olivella, S. (2005). A double structure generalized plasticity model for expansive materials. Innternational Journal for Numerical and Analytical Methods in Geomechanics 29, No. 8, 751-787.

Siemens, G., Blatz, J.A. (2009). Evaluation of the influence of boundary confinement on the behaviour of unsaturated swelling clay soils. Canadian Geotechnical Journal, 46: 330-356.

Smith, C.W., Johnston, M.A. \& Lorentz, S. (1997). Assessing the compaction susceptibility of South African forestry soils. II. Soil properties affecting compactibility and compressibility. Soil \& Tillage Research 43, No. 3, 335-354.

Tang, A. M. \& Cui, Y. J. (2005). Controlling suction by the vapour equilibrium technique at different temperatures and its application in determining the water retention properties of MX80 clay. Can. Geotech. J., 42 (1), 287-296.

Tang, A. M., Cui, Y. J. \& Barnel, N. (2008). Thermo-mechanical behaviour of a compacted swelling clay. Géotechnique 58(1), 45-54.

Tang A.M. \& Cui Y.J. (2009). Modelling the thermo-mechanical behaviour of compacted expansive clays. Géotechnique 59 (3), 185-195.

Tang, C.S., Cui, Y.J., Tang, A.M. \& Shi, B. (2009). Compression behavior of crushed COx argillite used as backfilling material in HLW repository. Chinese Journal of Rock Mechanics and Engineering 28, No. 12, 2459-2465.

Tarantino, A. \& De Col E. (2008). Compacted behaviour of clay. Géotechnique 58, No. 3, 199-213.

Tien, Y.M., Wu, P.L., Chuang, W.S. \& Wu, L.H. (2004). Micromechanical model for compaction characteristics of bentonite-sand mixtures. Applied Clay Science 26, No. 14, 489-498.

Villar, M.V., 2007. Water retention of two natural compacted bentonites. Clays and Clay Minerals, 55(3): 311-322.

Wileveau, Y., Cornet, F.H., Desroches, J. \& Blumling, P. (2007). Complete in situ stress determination in an argillite sedimentary formation. Physics and Chemistry of the Earth 32, No. 8-14, 866-878.

Wright, H., Le Cléac'h, J.M. \& Deveughèle, M. (2001). Altération et rupture d'échantillon d'argilite lors de sollicitations thermomécaniques en conditions humides contrôlées. Bull. Eng. Geol. Env. 60, 59-67.

Ye W.M., Cui Y.J., Qian L.X., Chen B. (2009). An experimental study of the water transfer through compacted GMZ bentonite. Engineering Geology 108, 169 - 176.

Zhang, C.L., Rothfuchs, T., Su, K., Hoteit, N. (2007). Experimental study on the thermo-hydromechanical behaviour of indurated clays. Physics and Chemistry of the Earth 32, 957-965. 


\section{List of Tables}

Table 1. Test program

\section{List of Figures}

Fig. 1. Grain size distribution curves of the two soils, A and B.

Fig. 2. Schematic view of the 1-D compression test.

Fig. 3. Compression behaviour: dry density versus vertical stress.

Fig. 4. Compression behaviour: void ratio versus vertical stress.

Fig. 5. Compression behaviour: swelling index at initial water content versus dry density.

Fig. 6. Vertical stress and void ratio changes during flooding under constant-volume conditions.

Fig. 7. Oedometers tests on resaturated samples. (a) Void ratio versus time and (b) logarithm of vertical stress.

Fig. 8. Results of MIP tests on soil A and intact COx argillite.

Fig. 9. Results of MIP tests on soil B and intact COx argillite.

Fig. 10. SEM pictures of soil samples having $\rho_{\mathrm{d}}=2.0 \mathrm{Mg} / \mathrm{m}^{3}$ (Dimension of pictures: $125 \times 100$ $\mu \mathrm{m})$.

Fig. 11. SEM pictures of soil samples having $\rho_{d}=2.0 \mathrm{Mg} / \mathrm{m}^{3}$ (Dimension of pictures: $25 \times 20 \mu \mathrm{m}$ ). 
Table 1. Test program

Test Soil Procedure

E01 A Compacted at constant rate of $0.05 \mathrm{~mm} / \mathrm{min}$ to $\rho_{\mathrm{d}}$ equal to $2.0 \mathrm{Mg} / \mathrm{m}^{3}$ with unloading/reloading cycles at lower $\rho_{d}$ of $1.7,1.8,1.9 \mathrm{Mg} / \mathrm{m}^{3}$, then flooded at $\sigma_{v}$ equal to $7 \mathrm{MPa}$

E02 A Compacted at constant rate of $0.05 \mathrm{~mm} / \mathrm{min}$ to $\rho_{\mathrm{d}}$ equal to $2.0 \mathrm{Mg} / \mathrm{m}^{3}$ with unloading/reloading cycles at lower $\rho_{d}$ of $1.7,1.8,1.9 \mathrm{Mg} / \mathrm{m}^{3}$, then flooded at $\sigma_{v}$ equal to $0.5 \mathrm{MPa}$

E03 B Compacted at constant rate of $0.05 \mathrm{~mm} / \mathrm{min}$ to $\rho_{\mathrm{d}}$ equal to $2.0 \mathrm{Mg} / \mathrm{m}^{3}$ with unloading/reloading cycles at lower $\rho_{d}$ of $1.7,1.8,1.9 \mathrm{Mg} / \mathrm{m}^{3}$, then flooded at $\sigma_{v}$ equal to $7 \mathrm{MPa}$

E04 B Compacted at constant rate of $0.05 \mathrm{~mm} / \mathrm{min}$ to $\rho_{\mathrm{d}}$ equal to $2.0 \mathrm{Mg} / \mathrm{m}^{3}$ with unloading/reloading cycles at lower $\rho_{d}$ of $1.7,1.8,1.9 \mathrm{Mg} / \mathrm{m}^{3}$, then flooded at $\sigma_{v}$ equal to $0.5 \mathrm{MPa}$

E05 A Compacted at constant rate of $0.05 \mathrm{~mm} / \mathrm{min}$ to $\rho_{\mathrm{d}}$ equal to $2.0 \mathrm{Mg} / \mathrm{m}^{3}$ and then flooded at $\sigma_{v}$ equal to $0.5 \mathrm{MPa}$

E06 B Compacted at constant rate of $0.05 \mathrm{~mm} / \mathrm{min}$ to $\rho_{\mathrm{d}}$ equal to $2.0 \mathrm{Mg} / \mathrm{m}^{3}$ and then flooded at $\sigma_{v}$ equal to $7 \mathrm{MPa}$

E07 A Flooded at constant $\sigma_{v}$ equal to $0.1 \mathrm{MPa}$ then loading/unloading step-by-step

E08 B Flooded at constant $\sigma_{v}$ equal to $0.1 \mathrm{MPa}$ then loading/unloading step-by-step 


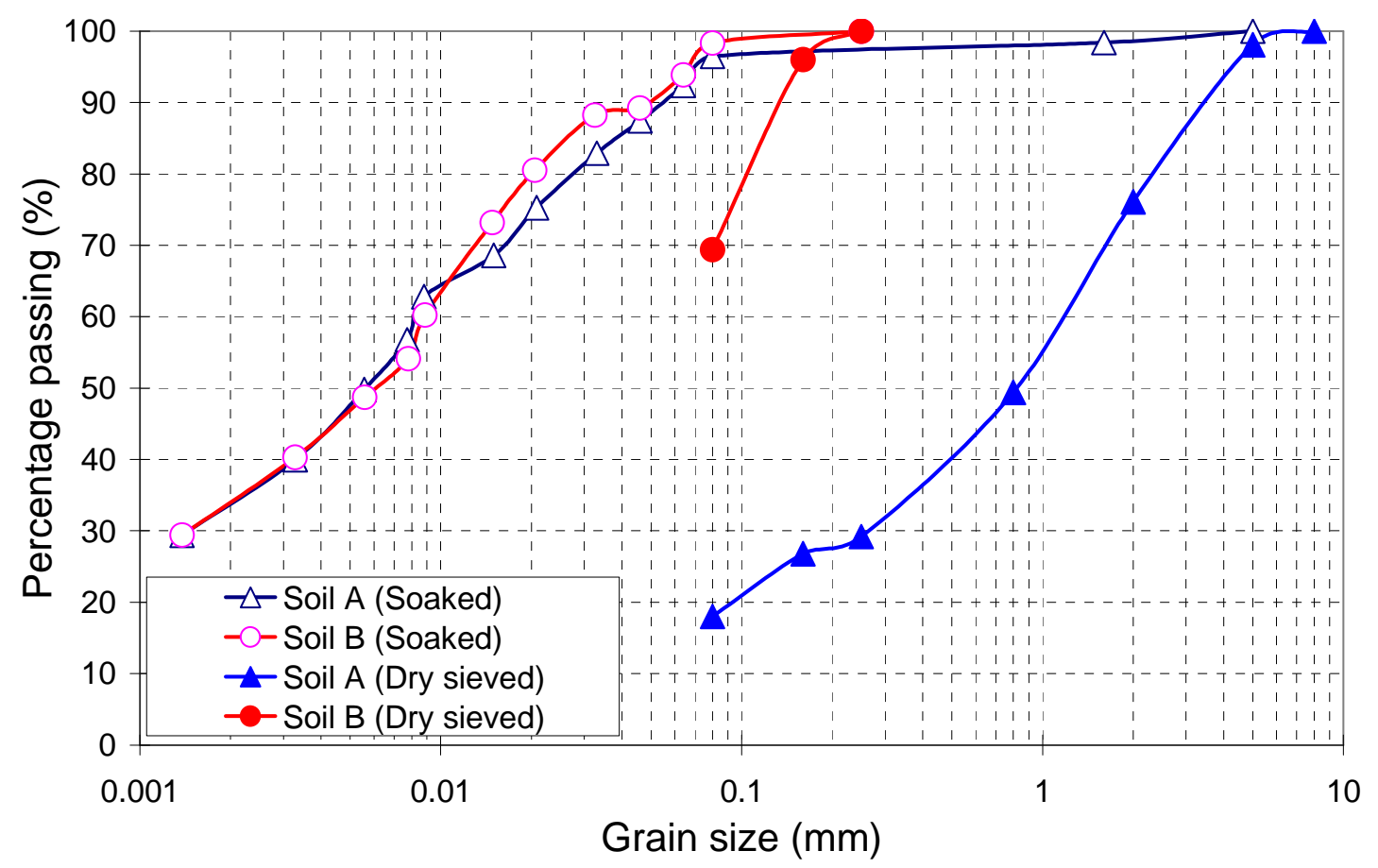

Fig. 1. Grain size distribution curves of the two soils, $A$ and $B$. 


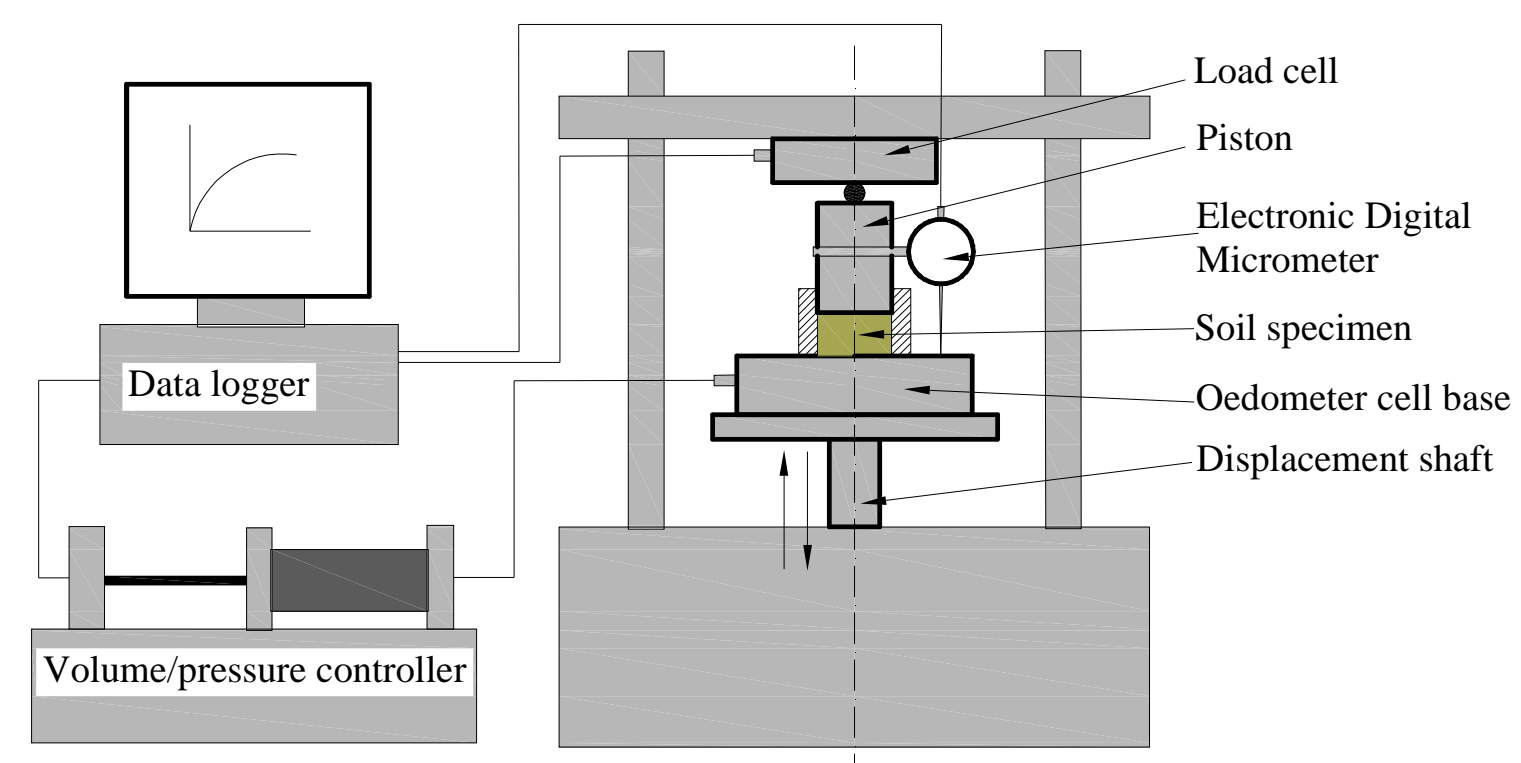

Fig. 2. Schematic view of the 1-D compression test. 


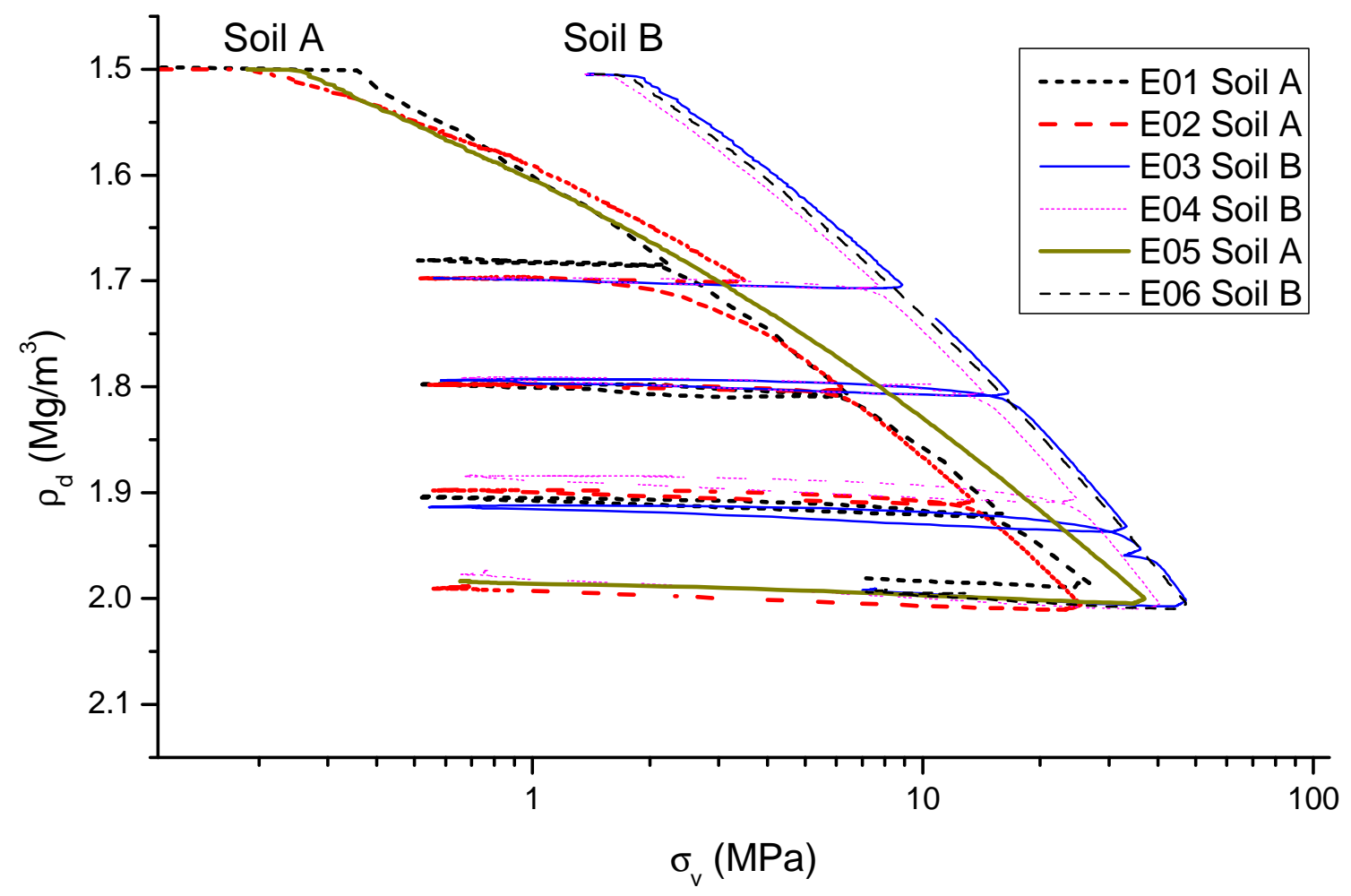

Fig. 3. Compression behaviour: dry density versus vertical stress. 


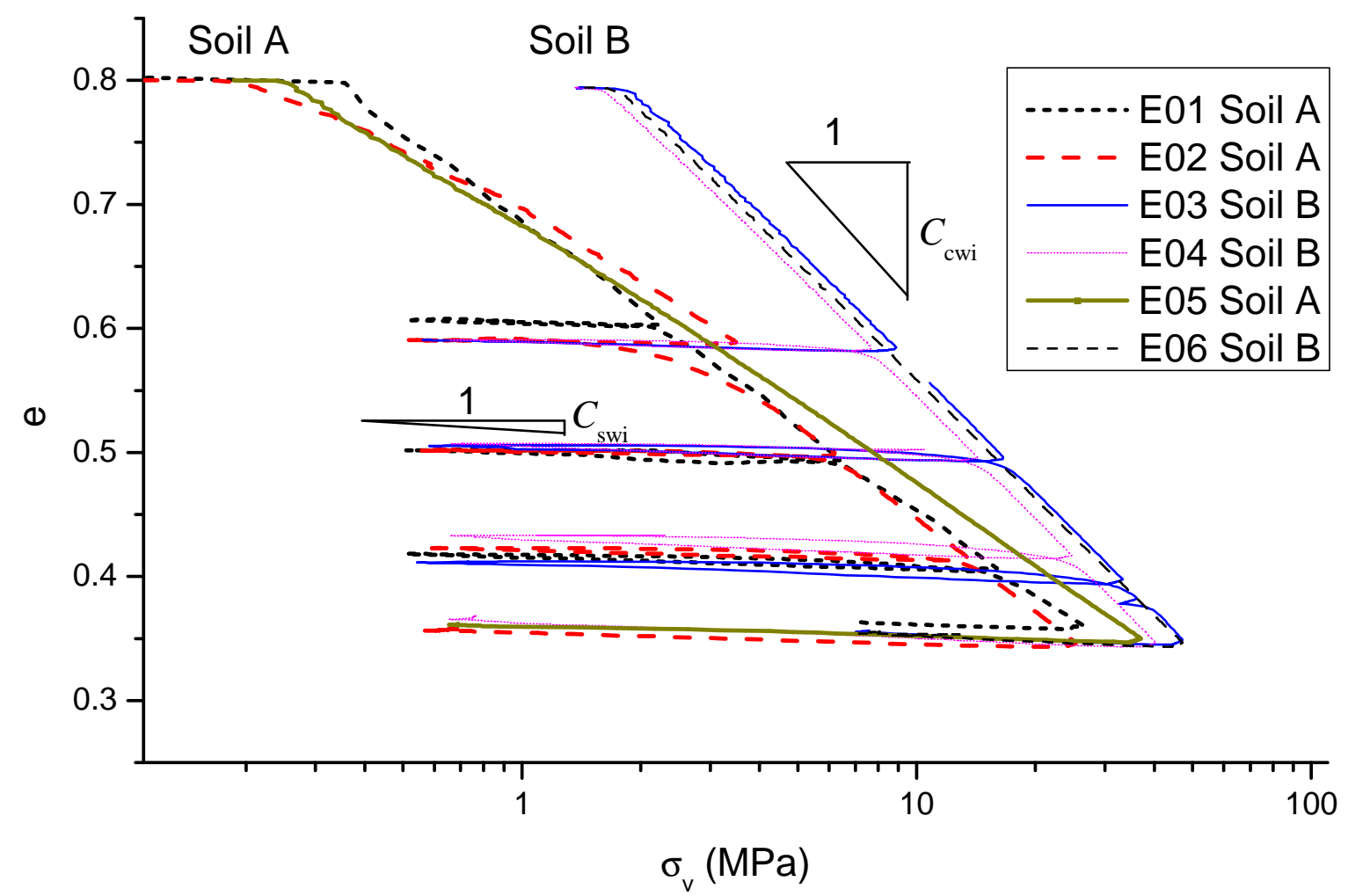

Fig. 4. Compression behaviour: void ratio versus vertical stress. 


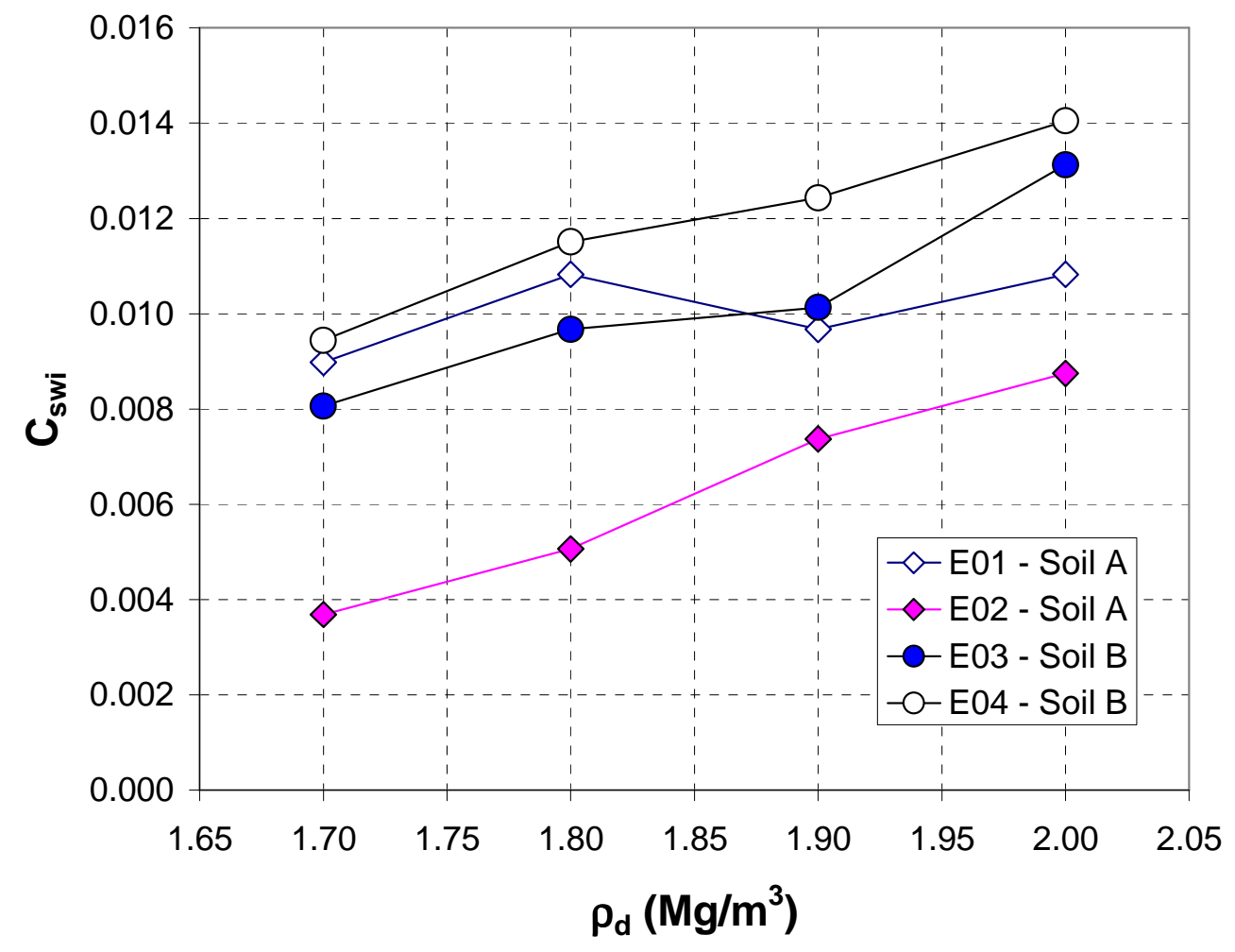

Fig. 5. Compression behaviour: swelling index at initial water content versus dry density. 

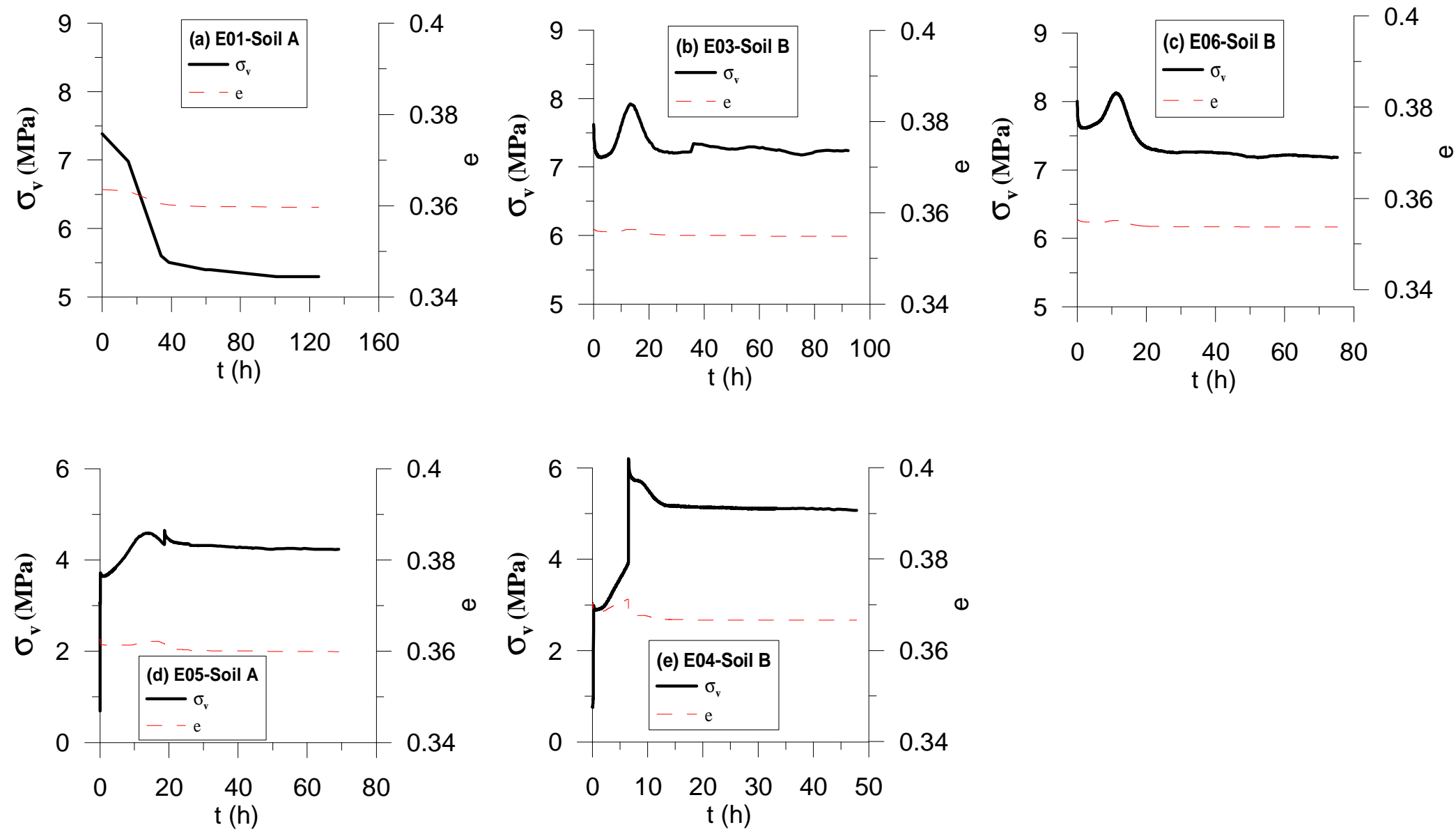

Fig. 6. Vertical stress and void ratio changes during flooding under constant-volume conditions. 

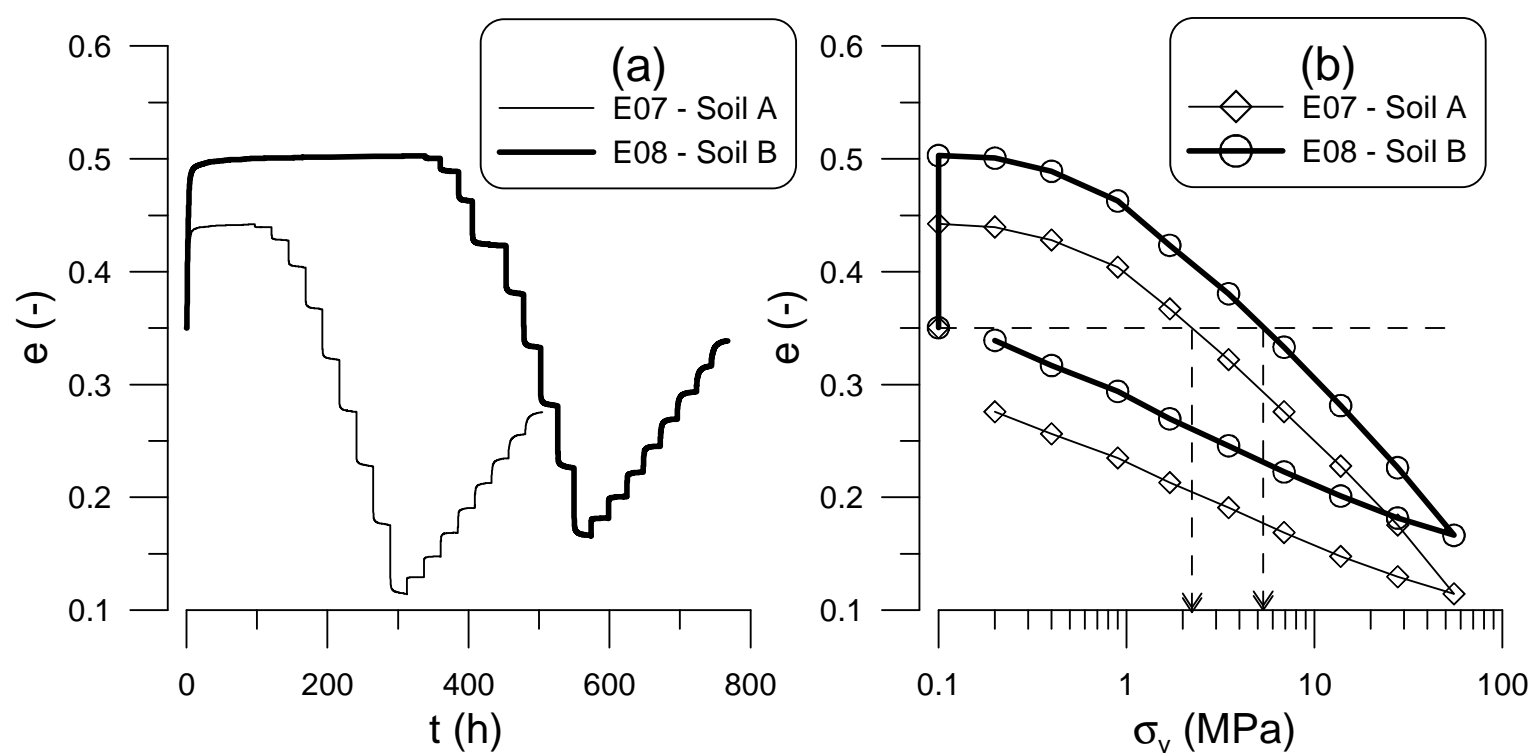

Fig. 7. Oedometers tests on resaturated samples. (a) Void ratio versus time and (b) logarithm of vertical stress. 


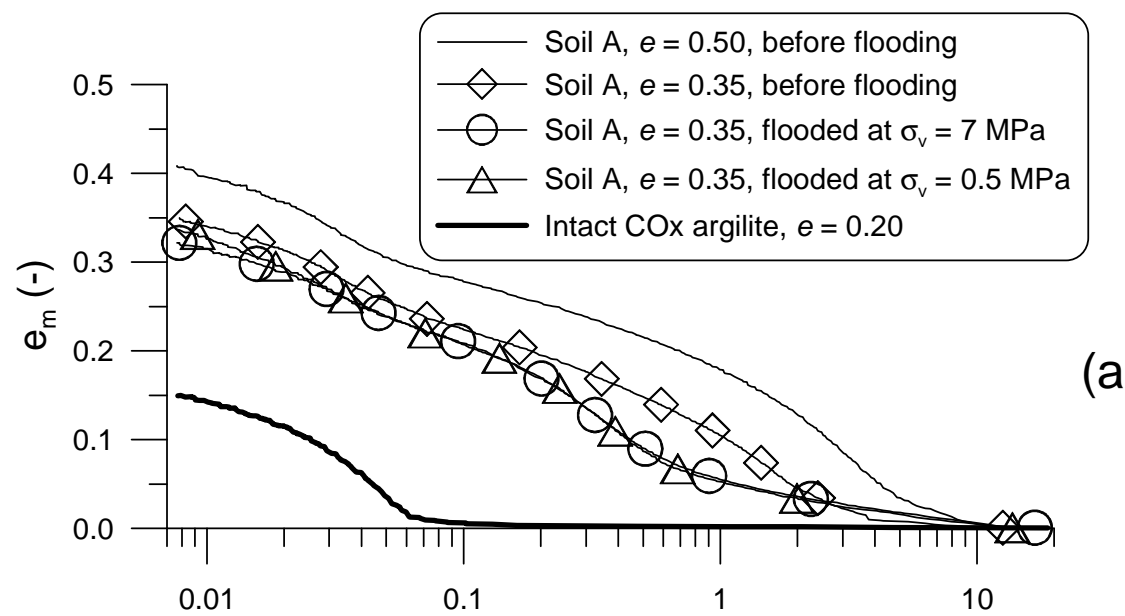

(a)

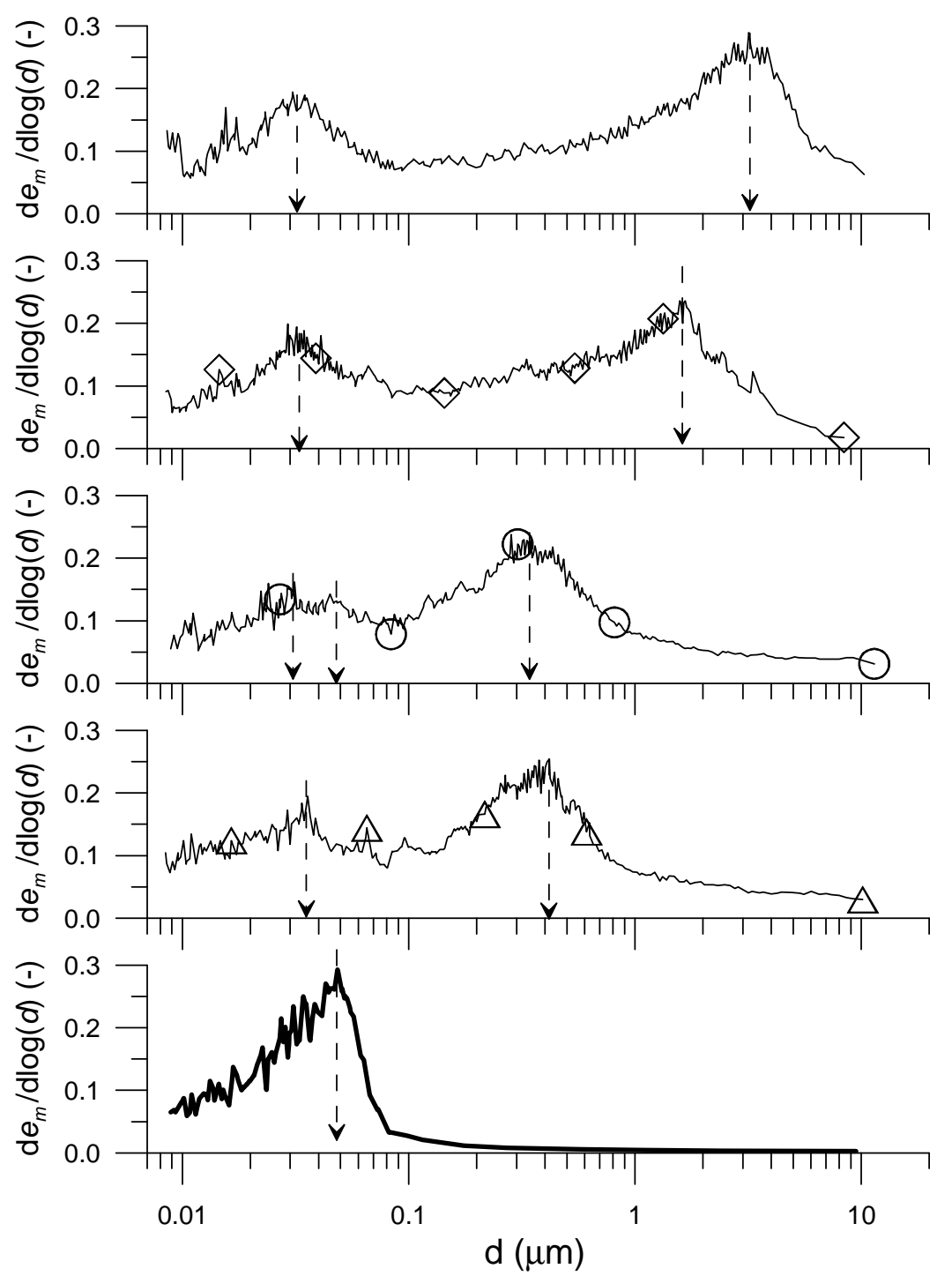

(b)

(e)

Fig. 8. Results of MIP tests on soil A and intact COx argillite. 


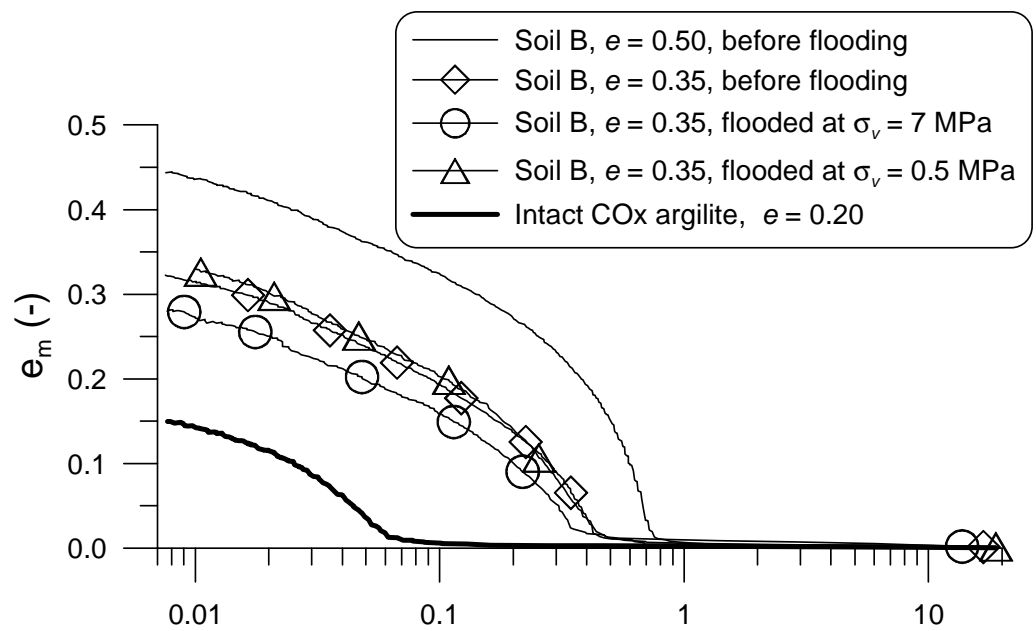

(a)

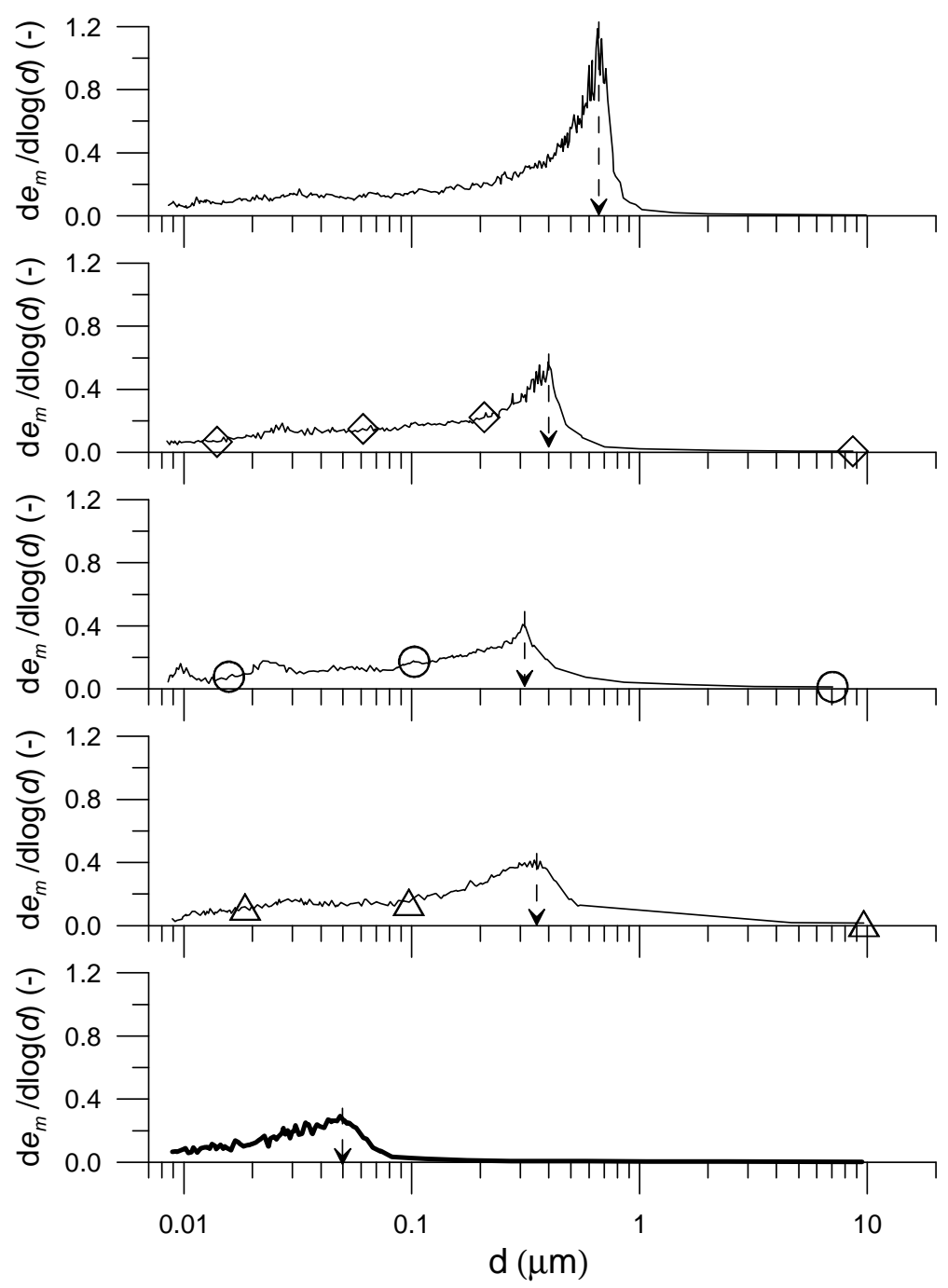

(b)

(c)

(d)

(e)

(f)

Fig. 9. Results of MIP tests on soil B and intact COx argillite. 


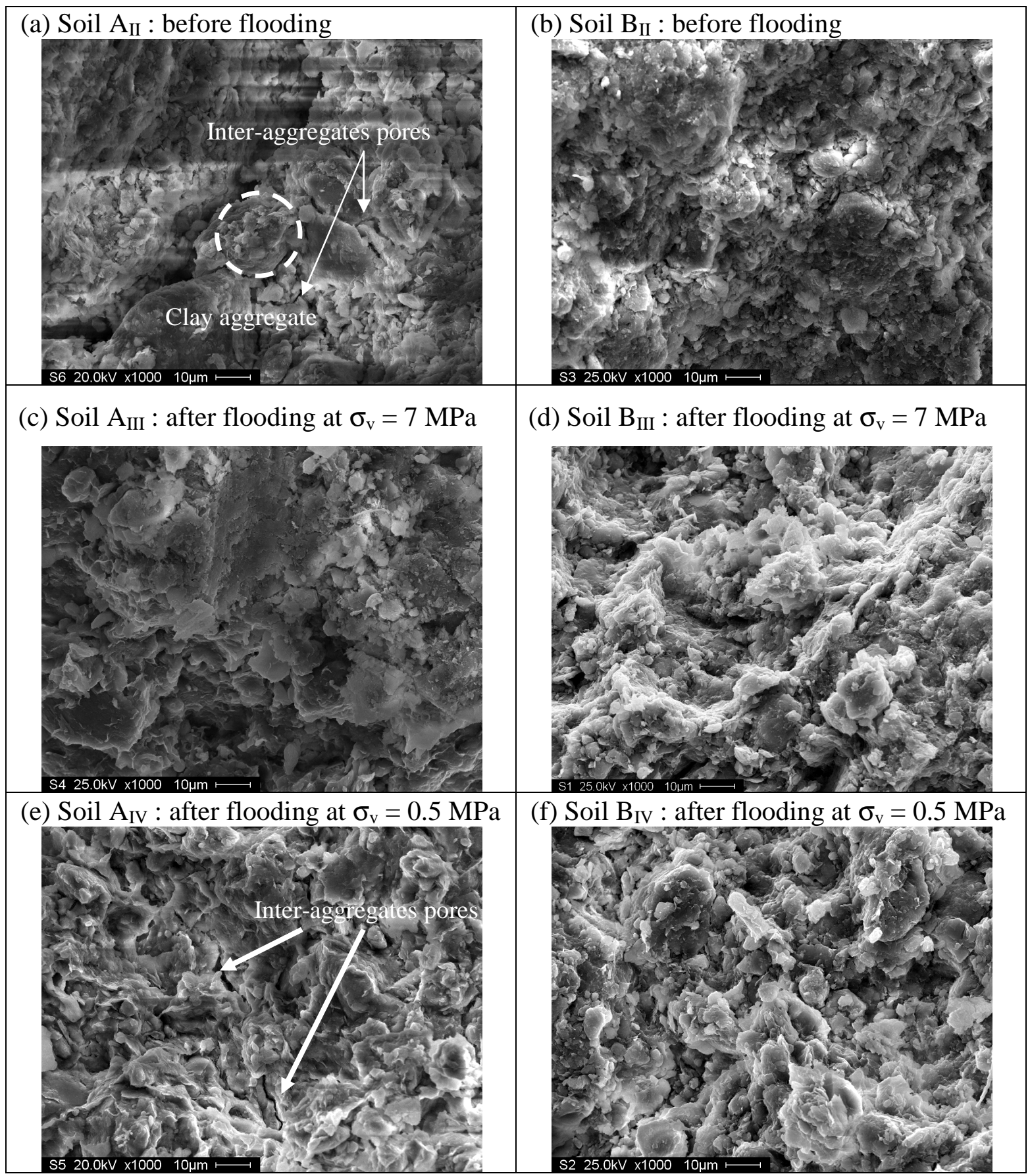

Fig. 10. SEM pictures of soil samples having $\rho_{d}=2.0 \mathrm{Mg} / \mathrm{m}^{3}$ (Dimension of pictures: $125 \times 100 \mu \mathrm{m}$ ). 


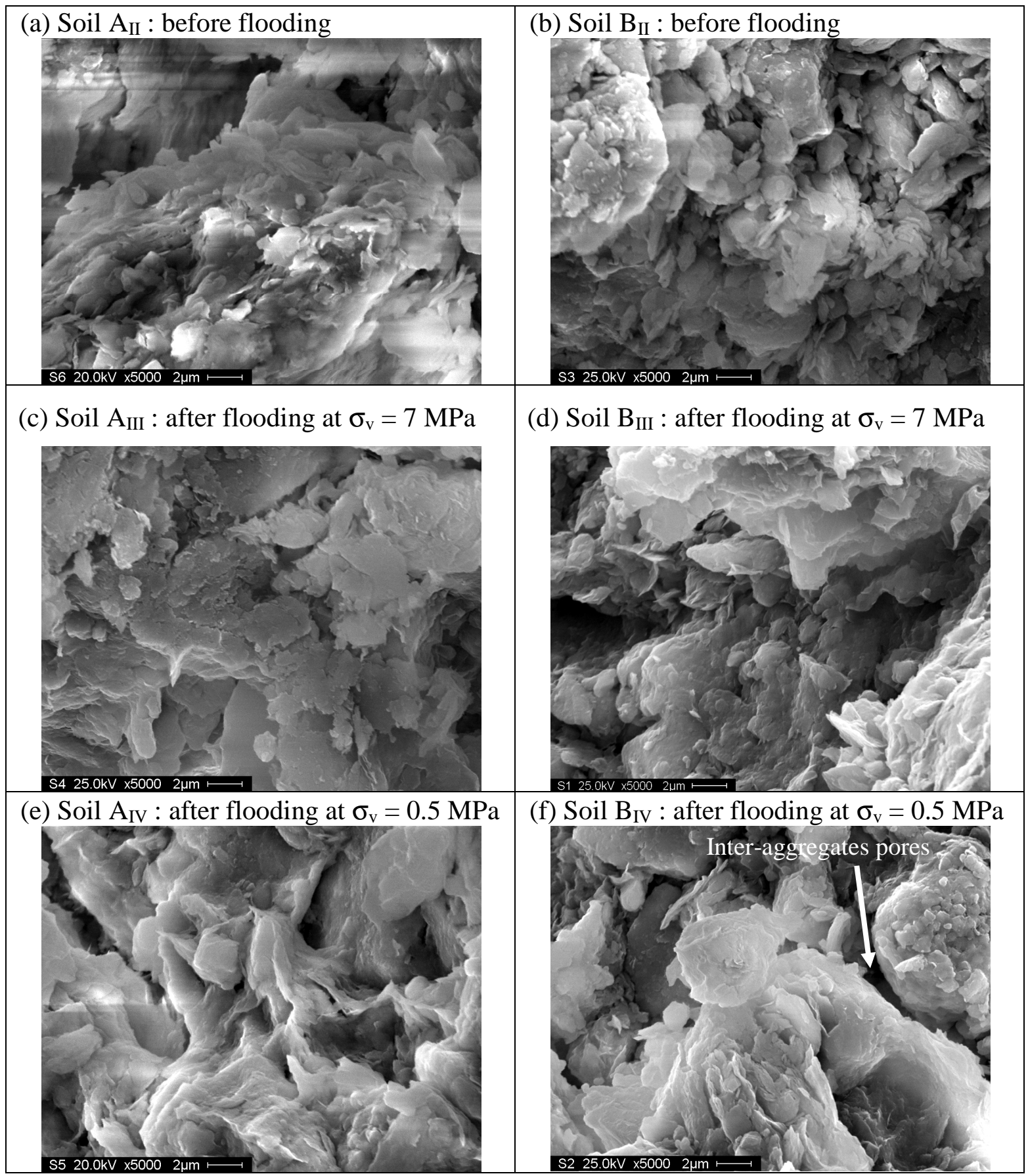

Fig. 11. SEM pictures of soil samples having $\rho_{d}=2.0 \mathrm{Mg} / \mathrm{m}^{3}$ (Dimension of pictures: $25 \times 20 \mu \mathrm{m}$ ). 